Working Paper in Economics No. 765

\title{
Experimental Evidence on Cooperation, Political Affiliation, and Group Size
}

Ronja Helénsdotter

Department of Economics, May 2019 


\title{
Experimental Evidence on Cooperation, Political Affiliation, and Group Size ${ }^{\circ}$
}

\author{
Ronja Helénsdotter ${ }^{\mathrm{a}, *}$ \\ ${ }^{\mathrm{a}}$ Department of Economics, University of Gothenburg, Box 640, 40530 Gothenburg, Sweden
}

\begin{abstract}
The main objective of this paper is to strengthen the knowledge about the relationship between cooperation and political affiliation. For this purpose, I carry out an incentivized Nperson prisoner's dilemma experiment. I find that left-wing voters cooperate more than right-wing voters in 3-person prisoner's dilemmas. However, this difference in cooperation tapers off with group size due to a heterogeneous response to larger decision groups. While leftists cooperate less as the group size increases, I find no significant group size effect for rightists. These findings can partly be explained by differences in beliefs about the cooperativeness of others, but a substantial part remains unexplained.
\end{abstract}

Keywords: Cooperation, Social dilemma, Political ideology, Group size, Experiment JEL-codes: C71, C90, D70, D84

\footnotetext{
${ }^{\circ}$ I gratefully acknowledge the funding provided by the Centre for Collective Action Research (CeCAR) at the University of Gothenburg. The sponsor had no involvement in the research presented in this paper. I would also like to express my deepest gratitude to Elina Lampi for her invaluable help during the process of writing this paper. I thank Jens Ewald, Joakim Ruist, Olof Johansson-Stenman, Simon Lundin, and Toke Fosgaard for comments.

* Corresponding author at: Department of Economics, University of Gothenburg, Box 640, 40530 Gothenburg, Sweden. Email address: ronja.helensdotter@economics.gu.se (R. Helénsdotter).
} 


\section{Introduction}

Cooperation is a fundamental element of human society. At all levels - from managing a small household, to passing a bill, to battling climate change - cooperation is at the center. To facilitate cooperation, and thereby social progress, we need to understand the determinants of cooperation as well as the underlying mechanisms. This paper focuses on one (possible) determinant that has received surprisingly little attention: political ideology. As we stand before great challenges such as climate change and biodiversity loss, which will require extensive cooperation by people from the entire political spectrum, it is important to identify behavioral similarities and differences. It is especially important to study the role of political ideology in the context of different decision group sizes given the large degree of variation in the situations we need to cooperate in. To tackle the challenges of today, we need to find ways to cooperate with a few coworkers, a dozen neighbors, thousands of strangers, and beyond. In this paper, I primarily investigate differences in cooperation rate between left-wing and right-wing voters when the decision environment is altered in terms of decision group size. I then explore whether beliefs can explain these behavioral differences.

To this end, I conducted an incentivized, one-shot N-person prisoner's dilemma (NPD; see Section 2 for a description) experiment in a web survey format. The participants were allocated to one of three treatments. The NPD presented in each treatment varied in terms of group size. Three sizes were used: 3-person groups (SmallSize), 7-person groups (MedSize), and 25person groups (LargeSize). For more details about the experimental design, see Section 3.

The main analysis of this paper is based on answers from 211 Swedish university students. I find that left-wing voters cooperate more than right-wing voters in 3-person prisoner's dilemmas (PDs). However, this difference in cooperation tapers off with group size due to a heterogeneous response to larger decision groups. While leftists cooperate less as the group size increases, I find no significant difference for rightists. In other words, the effect of larger group sizes is heterogeneous and varies with political affiliation. Subsequently, when the group size is set to 7 or 25 , no significant difference in cooperation rate between leftists and rightists is detected. These findings can to some extent be explained by deviating beliefs about the other group members' behavior, but a substantial part remains unexplained.

The focus of this paper is on the cooperative behavior of people along the linear left-right political spectrum ranging from communism at the far left to socialism, liberalism, conservatism, and finally fascism at the far right. One of the key features of this spectrum is the attitudes toward the economy and the government. While collectivism and government intervention is 
favored by those to the left of the spectrum, individualism and the free market is favored by those to the right. If a broader definition of the political left-right dimension is adopted, additional value differences can be ascribed to the left and the right. Generally, the left is associated with concepts such as equality, progress, reform, and internationalism while the right is associated with for example authority, order, tradition, and nationalism (Heywood 2015). These deviating values may lead people to the left and the right of the political spectrum to behave differently when faced with a conflict between collective and individual interests. For example, given that previous research has found that inequality aversion is a driver of cooperation (e.g. Fehr \& Schmidt 1999; Van Lange 1999), the stronger presence of egalitarianism within the left may lead leftists to cooperate to a greater extent than rightists. In addition, the larger degree of individualism, as opposed to collectivism, within the right might imply less concern for other's outcomes. Thus, rightists may be more likely than leftists to prioritize their own interests. Indeed, previous research has found that political affiliation is related to social value orientation (SVO), where SVO is a concept capturing a person's concern for self and others' outcomes. Specifically, people to the left on the political spectrum show more concern for others' outcomes than people to the right (see Balliet et al. 2018 for a meta-analysis). SVO has in turn been found to be positively related to cooperation in various situations (Van Lange et al. 1997; Balliet et al. 2009).

Given that there is cause to suspect a relationship between political ideology and cooperation, it is surprising how few studies have been conducted on the topic in the past. ${ }^{1}$ One paper that has addressed the question is Anderson et al. (2005). They studied public good contributions in relation to ideology using American undergraduate students but found no connection. However, they employed a sample of mere 48 students, while I use a sample of 211 students. Recently, another study was conducted in the U.S. in which the choices of Democrats and Republicans were compared in a PD (Balliet et al. 2018). Unfortunately, in this experiment, the participants were informed about the political ideology of their co-player, which could explain why no relationship between political affiliation and cooperation was detected. Lastly, Fosgaard et al. (2019) studied how ideology relates to cooperation using a give- or take-framed public goods game (PGG) in which the participants were grouped into sets of four. They found that

\footnotetext{
${ }^{1}$ Some research has been conducted on how political attitude relates to behavior in dictator game experiments. A few studies have reported that leftists give more than rightists in such games (Dawes et al. 2012; Cappelen et al. 2017; Muller 2017). However, Thomsson and Vostroknutov (2017) were unable to detect a difference in giving between leftists and rightists. Moreover, Fisman et al. (2017) found that leftists are more equality-focused as opposed to efficiency-focused in a generalized dictator game. Heterogeneous behavior has been detected in other controlled experiments as well. In a preference elicitation task, Kerschbamer and Muller (2017) and Muller and Renes (2017) found that people on the right side of the political spectrum make selfish choices to a greater extent.
} 
leftists contribute more than rightists in a take frame. In contrast, no significant difference was detected in a give-framed PGG. ${ }^{2}$ My paper adds to this literature by being the first to investigate cooperation differences due to political ideology in the context of fully anonymous PDs. In addition, I am the first to study the role of political ideology for cooperation when a large decision group size is employed. Of the three previously mentioned studies, Anderson et al. (2005) is the paper that uses the largest group size (eight members). Since we are currently facing pressing issues that will require large-scale cooperation, such as climate change and resource depletion, it is of utmost importance to have knowledge about how people with different ideologies may differ in their responses to having to cooperate in larger groups. Thus, in my paper, a decision group of as many as 25 members is used, in addition to groups of seven and three members.

By investigating cooperation differences due to political affiliation in differently sized groups, I also make a contribution to the literature on the group size effect. A number of empirical studies have found evidence that cooperation decreases with increasing group size in NPDs (Marwell \& Schmitt 1972; Kahan 1973; Hamburger et al. 1975; Bonacich et al. 1976; Fox \& Guyer 1977; Komorita \& Lapworth 1982; Grujić et al. 2012; Barcelo \& Capraro 2015; Bosch-Domènech \& Silvestre 2017). ${ }^{3}$ However, to the best of my knowledge, no research has been conducted on how the group size effect varies with political affiliation.

A heterogeneous response is expected if leftists and rightists are affected differently by the mechanisms behind the group size effect. Unfortunately, little research has been conducted on the underlying mechanisms of the negative group size effect in NPDs. One hypothesis is that because the individual cost and individual benefit at full cooperation are constant with group size, but more people need to cooperate to reach said benefit, cooperation is expected to decrease with group size. ${ }^{4}$ This hypothesis is discussed in, for example, Barcelo and Capraro (2015). If the beliefs of leftists and rightists are heterogeneously affected by game characteristics, which Fosgaard et al. (2019) found some empirical support for, it is possible that leftists

\footnotetext{
${ }^{2}$ In short, a give frame implies that participants choose what amount to give to a common pool, while a take frame implies choosing what amount to take from a common pool.

${ }^{3}$ I find only one study that has reported a positive group size effect in NPDs, namely Duffy and Xie (2016).

${ }^{4}$ Changes in the diffusion of harm may be another explanation for the negative group size effect. As the group size grows, the harm directed to any single person by choosing to defect decreases. In other words, the impact of one individual's action on the payoff for another group member diminishes with size. This concept of diffusion is discussed in Dawes (1980). If people tend to cooperate less as the diffusion of harm increases, we should observe less cooperation as the group size increases. Given that previous research has found that concern for others' outcomes is related to political orientation (see Balliet et al. 2018), leftists and rightists might respond heterogeneously to this diffusion of harm.
} 
and rightists respond differently to the increased number of required cooperators due to deviating perceptions of the likelihood of a fellow student cooperating.

A substantial body of previous literature has found empirical evidence that expectations regarding other people's behavior are positively related to cooperation in social dilemmas (e.g., Deutsch 1960; Dawes 1980; Messic \& Brewer 1983; Yamagishi 1986, 1988; Fischbacher et al. 2001; Ferrin et al. 2008), which means that a person who believes that others cooperate is more likely to cooperate as well. To explore the role of beliefs in explaining cooperation differences associated with political ideology, I elicited the participants' beliefs when they had completed the social dilemma by asking them to choose how many other students they believe had cooperated in the NPD.

The remainder of this paper is organized as follows. Section 2 provides a description of NPDs. Section 3 outlines the experimental design and implementation, Section 4 presents the results, and Section 5 concludes the paper.

\section{N-Person Prisoner's Dilemmas}

A social dilemma is a situation in which individual rationality and collective rationality are in opposition. One type of social dilemma is the so-called prisoner's dilemma, where the participants have only two options: cooperate or defect. The PD is a social dilemma since the payoff to a single participant for defecting is always higher than the payoff for cooperating, but all participants receive a lower payoff if everyone defects compared with if everyone cooperates (see Dawes 1980). In the standard 2-person version, there are four possible outcomes: both participants cooperate (CC); Participant 1 cooperates while Participant 2 defects (CD); Participant 1 defects while Participant 2 cooperates (DC); and both participants defect (DD). From the perspective of Participant 1, the best possible outcome is defecting while Participant 2 cooperates (DC); the next best outcome is full cooperation (CC); the third best outcome is full defection (DD); and the worst outcome is cooperating while Participant 2 defects (CD). The equivalent ranking of outcomes applies to Participant 2 (Kollock 1998).

The standard PD can be extended to include more than two participants, which is then referred to as the N-person prisoner's dilemma. However, the properties of the dilemma change to some extent when there are more than two participants. Firstly, when one person chooses to defect in the PD, the harm of that decision is focused on the co-player, while the harm is diffused throughout the group in the NPD. Secondly, each participant in the PD knows what decision 
their co-player made, whereas the decision is not necessarily revealed in the NPD. Thus, greater anonymity can be achieved in the NPD (Dawes 1980). ${ }^{5}$

The characteristics of the NPD used in my experiment are typical within the literature: (1) the payoffs are symmetric, (2) the game is run once, (3) each participant can either cooperate or defect, (4) a strictly dominant strategy exists, and (5) full cooperation is the Pareto-efficient outcome. The payoff to Participant $i$ for each possible outcome follows from Equation 1: ${ }^{6}$

$$
\frac{b X_{-i}}{N-1}-c A_{i}
$$

where $b$ is the benefit, $c$ the cost, $A_{i}$ a dummy taking the value 1 if Participant $i$ chooses to cooperate, $X_{-i}$ is the number of cooperators other than $i$, and $N$ is the total number of participants.

Two key aspects of the NPD's payoff structure are the benefit and the cost. My benefit is set to 48 SEK and the cost to $16 \mathrm{SEK},{ }^{7}$ resulting in a benefit-cost ratio of 3 (48 divided by 16). ${ }^{8}$ Table 1 presents the personal payoffs possible when Participant $i$ chooses Option A (cooperation) or Option B (defection) in the 3-person version of the NPD. ${ }^{9}$ See the appendix for tables containing the payoff matrices used in the 7- and 25-person versions.

Table 1.

Personal payoff matrix in the 3-person PD (SmallSize) when Participant $i$ chooses Option A or B.

Choices of the other 2 participants in the NPD

One cooperates,
one defects $\quad$ Both defect

\begin{tabular}{|c|c|c|c|}
\hline $\begin{array}{l}\text { Option A } \\
\text { (Cooperation) }\end{array}$ & 48 SEK & 24 SEK & 0 SEK \\
\hline $\begin{array}{l}\text { Option B } \\
\text { (Defection) }\end{array}$ & 64 SEK & $40 \mathrm{SEK}$ & 16 SEK \\
\hline
\end{tabular}

\footnotetext{
${ }^{5}$ If three people participate in the NPD and two people choose to defect, the third person knows the decision of the other two. Thus, greater anonymity is not certain in the NPD.

${ }^{6}$ The equivalent payoff structure is used in, e.g., Barcelo and Capraro (2015).

${ }^{7}$ Average in March, 2018, USD $1=$ SEK 8.23 (Statistics Sweden 2017). Thus, b $\approx 5.8$ USD and $\mathrm{c} \approx 1.9$ USD.

${ }^{8}$ Unfortunately, no standard benefit-cost ratio exists within the literature. My benefit-cost ratio of 3 is in accordance with, e.g., Dreber et al. (2012) and Barcelo and Capraro (2015).

${ }^{9}$ Note that the choice of setting the lowest payoff to zero, instead of a positive integer, could affect the decisionmaking in NPDs. Unfortunately, whether the lowest payoff is equal to zero or not varies between experiments. To name a few, Eiser and Bhavnani (1974), Dreber et al. (2012), and Barcelo and Capraro (2015) all use zero as the lowest possible payoff in their experiments.
} 


\section{Experiment}

The NPD experiment was conducted online, with a maximum payoff of 70 SEK per subject. The subjects were allocated to one of three treatments with different sized decision groups. ${ }^{10}$ As discussed by, e.g., Dawes (1980), a pair of individuals has characteristics that are distinctly different from those of a group. Since the interest of this paper is cooperation within groups, the small group size was set to three rather than two participants. The large group size was set to 25 participants, as this is the second largest group size for which the payoffs were guaranteed to be integers. ${ }^{11}$ Integer values were important to be able to provide the participants with their full earnings in cash. The medium size was then set to seven as this size also ensured integer payoffs and has been previously used in comparison with 3-person groups by Hamburger et al. (1975). Hence, the group sizes used were three (SmallSize), seven (MedSize), and 25 (LargeSize).

The experiment was executed by sending an email to the university email accounts of 2,173 undergraduate students at the University of Gothenburg in March 2018. Reminders were sent 4-5 days after the first invitation. The students were enrolled in one of the following programs: Biology, Biomedical Analysis, Computer Science, Geography, Journalism, Law, Logistics, Marine Science, Mathematics, Pharmacy, Physics, Political Science, Public Administration, Social Work, and Systems Science. Economics and business administration studies were not included in the sample since they may be too familiar with NPDs. On average, the participants earned 38.7 SEK, with a median of 38 SEK, or approx. 4.7 and 4.6 USD, respectively. ${ }^{12}$

A blocking mechanism based on web browser cookies was applied to reduce the risk of students participating in the experiment multiple times. ${ }^{13}$ In the email, a link to the experiment was attached. The email and all instructions were written in Swedish to ensure that the participants would fully understand them (see the appendix for the translated instructions as well as screenshots of the original instructions). Upon opening the link, the experiment was introduced. The participants were then assigned to a treatment group based on whether they were born on an even (uneven) day in an even (uneven) month, which should result in a random allocation.

\footnotetext{
${ }^{10}$ A fourth treatment, designed to study label framing, existed as well. In this treatment, the group size was set to 25 but the NPD was referred to as "community dilemma" instead of "dilemma" in the instructions. Since the effect of label framing is not covered in this paper, the fourth treatment is not described in greater detail.

${ }^{11}$ The largest possible group size is 49 participants, but a group this big would result in an unreasonably long table of payoffs. As I deemed it important to provide the full list of payoffs to ensure that the participants had all the necessary information to make their decision, I chose the second largest group size (25 participants).

${ }^{12}$ Average in March, 2018, USD 1=SEK 8.23 (Statistics Sweden 2017).

${ }^{13}$ As the block was based on cookies, participants were unable to respond from the same device multiple times. However, if they used another device, they were not blocked. During the payment process, only one participant was discovered to have participated in the experiment twice. The second response was omitted from the analysis.
} 
The experiment consisted of four parts. In the first part, the participants were informed about the NPD and asked to decide whether to cooperate or defect. In the second and third parts, they were asked to motivate their decision and asked how many others they believed cooperated in the NPD, respectively. In the fourth part, they were asked some background questions. After Part 4, the payment options (cash, SWISH - a Swedish smartphone money transfer service, or relinquish payment) were presented and the personal information required to be able to pay the subjects was collected. To avoid participants being affected by subsequent parts and changing their previous choices, they could not go back to a previous page while completing parts 1-4. After part 4, the participants were allowed to return to the previous page.

In part 1, the participants were informed that they faced a dilemma together with 2,6 , or 24 other students (the number of co-players depended on which treatment they had been allocated to). The dilemma was introduced by describing the payoff mechanism, followed by four examples of extreme outcomes. The participants could also view the full list of possible outcomes by clicking a button on the screen. The payoff structure applied in this paper is described in Section 2.

After the dilemma had been introduced, the participants were asked to make their decision. Cooperation was labelled "Option A" and defection "Option B" to avoid any framing effect of strategy labels. After the participants had made their decision, they were asked whether it had been made randomly. If they answered "Yes," they moved straight on to part 3, where their beliefs were assessed. If they answered "No," the participants were asked to motivate their choice by picking 1-3 of the nine suggested reasons.

After providing reasons for their decisions, the participants moved on to the belief elicitation part (part 3). To assess the subjects' beliefs, they were asked to choose how many other students in their group they thought had picked Option A. If they provided the correct answer, they receive an additional 6 SEK. The instructions for the NPD were provided again to refresh their memory. For all treatments, there were three alternatives, corresponding to having low, medium, or high beliefs. For SmallSize, the alternatives were 0 students, 1 student, or 2 students. For MedSize, the alternatives were 0-2 students, 3-4 students, or 5-6 students. For LargeSize, the alternatives were $0-8$ students, $9-16$ students, or $17-24$ students. ${ }^{14}$

In the last part, the participants were asked questions about themselves (gender, age, income, and field of education), their interest in community issues, their familiarity with the pris-

\footnotetext{
${ }^{14}$ Note that for MedSize and LargeSize, the first alternative (low beliefs) includes one more student than the other two alternatives, which was necessary to ensure realistic ranges.
} 
oner's dilemma, and how difficult they perceived the dilemma instructions to be. The participants were also asked what party they would vote for had it been Election Day. A list of the most common parties in Sweden was provided in alphabetic order: the Center Party, the Christian Democrats, the Feminist Initiative, the Green Party, the Left Party, the Liberals, the Moderate Party, the Social Democratic Party, and the Sweden Democrats. ${ }^{15,16}$ In addition, the participants could choose "Don't want to answer," "Don't know," or “Other." In the main analysis of this paper, subjects who chose one of the following parties were categorized as leftists: the Feminist Initiative, the Green Party, the Left Party, or the Social Democratic Party. Subjects who chose one of the remaining parties (the Center Party, the Christian Democrats, the Liberals, the Moderate Party, or the Sweden Democrats) were categorized as rightists. ${ }^{17}$ While I categorize subjects as either left or right wing depending on party affiliation, Fosgaard et al. (2019) asked the subjects to place themselves on a political left-right scale (1=left and 10=right), where those who rated their views above 5 were categorized as rightists.

\section{Results}

The analysis is based on a total sample of 211 participants. Detailed information about the sample is available in the appendix. Note that an additional 107 students correctly completed the experiment. These students either answered that they did not know their political affiliation, did not want to disclose their affiliation, or specified a party not included on the list presented to them. As these participants cannot easily be categorized as rightists or leftists, they are excluded from the main analysis. ${ }^{18}$

The results are presented in four subsections. First, I conduct a non-parametric analysis, followed by a regression analysis. To delve deeper into the role of political preferences, I employ three categories of political preferences (GAL, CEN, TAN) in the third subsection. In the last subsection, I present some robustness checks.

\footnotetext{
15 The Swedish names are: Centerpartiet, Kristdemokraterna, Feministiskt initiativ, Miljöpartiet, Vänsterpartiet, Liberalerna, Moderaterna, Socialdemokraterna, and Sverigedemokraterna.

${ }^{16}$ Traditionally, only the Center Party, the Christian Democrats, the Green Party, the Left Party, the Liberals, the Moderate Party, and the Social Democratic Party have been represented in the Swedish Riksdag. However, during the last decade, the Sweden Democrats, a far-right party, has grown in popularity and is now represented in the Riksdag. In addition, although the Feminist Initiative is not currently represented in the Riksdag, they can be considered a key party within the younger population and were thus included as an option.

${ }^{17}$ At the time of the experiment, two major "blocks" existed in Swedish politics: the Alliance (Alliansen) and the Red-Greens (de rödgröna). The former (consisting of the Center Party, the Christian Democrats, the Liberals, and the Moderate Party) are considered to be the right-wing block, while the latter (consisting of the Social Democratic Party and the Green Party) are considered to be the left-wing block. During the election campaign of 2018, the parties within each block had declared an intention to jointly govern the country.

${ }^{18}$ As a robustness check, unsure voters are treated as a separate political affiliation category. When this is done, only 31 participants $(9.7 \%)$ are excluded.
} 


\subsection{Non-Parametric Testing}

Figure 1 displays the share of left-wing students (dark grey bars) and right-wing students (light grey bars) who cooperated in the NPD by treatment group. For leftists, the cooperation rate declines with group size (from $85 \%$ for 3-person groups to $71 \%$ for 7 -person groups and to 59\% for 25-person groups). Using Fisher's exact test, an overall p-value of 0.028 is obtained, which indicates that there is a negative group size effect for leftists. For rightists, on the other hand, no clear pattern is visible. Using the same test as for leftists, no difference in cooperation rate is significant for subjects categorized as rightists ( $\mathrm{p}$-value $=0.705$ ).

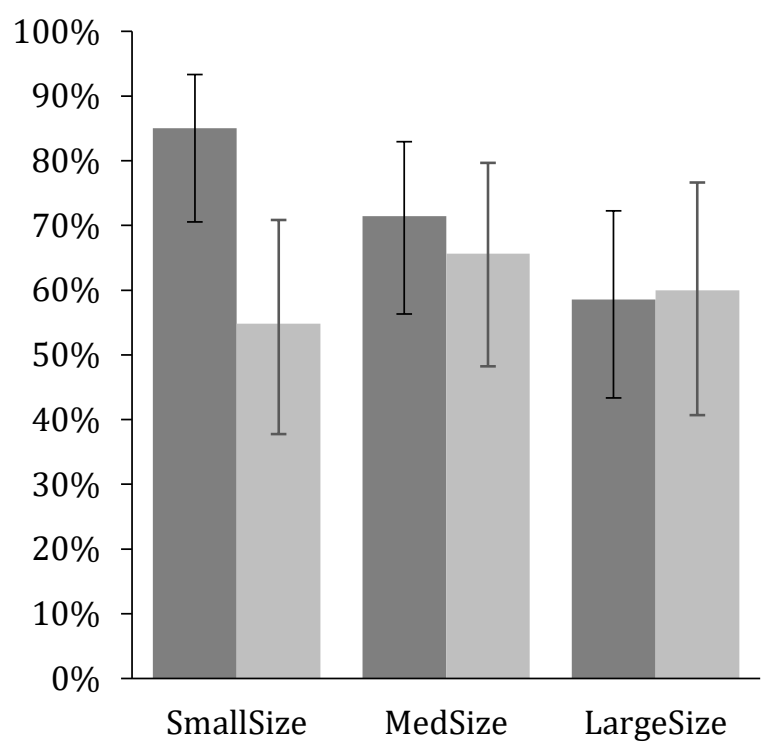

Figure 1. The share of leftists (123 obs.) and rightists (88 obs.) who cooperated in each treatment. Error bars display Agresti-Coull intervals at the $95 \%$ confidence level.

\subsection{Regression Analysis}

Table 2 presents the estimated coefficients for two linear probability models (LPM) with robust standard errors in parentheses. An LPM approach is used since all predictor variables are binary. ${ }^{19}$ In both models, the dependent variable is Cooperated, which takes the value 1 if the subject chose to cooperate. This variable is regressed on the treatment dummies; a dummy for rightists; a dummy for subjects older than the median age of 23; and a dummy for females. Additionally, in both models, political preference is interacted with treatment group, which means that the effects of the treatments are allowed to be heterogeneous. The base is leftists in

\footnotetext{
${ }^{19}$ Probit (or logit) regression is not an appropriate approach when all the predictor variables are binary.
} 
the 3-person PD. In Model 2, the categorical variable Beliefs is included (Low Beliefs=0, Medium Beliefs=1, and High Beliefs=2), where High Beliefs means that the participant believed that a high number of the other group members cooperated in the NPD. ${ }^{20}$

Table 2

Linear probability model regression. Dependent variable: Cooperation $=1$ for subjects who chose Option A. Base: leftists in 3-person PD, i.e., people who would vote for the Feminist Initiative, the Green Party, the Left Party, or the Social Democratic Party.

\begin{tabular}{|c|c|c|}
\hline VARIABLES & Model 1 & Model 2 \\
\hline \multirow[t]{2}{*}{ MedSize } & $-0.162 *$ & -0.049 \\
\hline & $(0.09)$ & $(0.08)$ \\
\hline \multirow[t]{2}{*}{ LargeSize } & $-0.298 * * *$ & $-0.170 *$ \\
\hline & $(0.10)$ & $(0.09)$ \\
\hline \multirow[t]{2}{*}{ Right Wing } & $-0.312 * * *$ & $-0.212 * *$ \\
\hline & $(0.10)$ & $(0.10)$ \\
\hline \multirow[t]{2}{*}{ Older $(>23)$} & $0.133 * *$ & 0.069 \\
\hline & $(0.07)$ & $(0.06)$ \\
\hline \multirow[t]{2}{*}{ Female } & -0.037 & -0.059 \\
\hline & $(0.06)$ & $(0.06)$ \\
\hline \multirow[t]{2}{*}{ MedSize*Right Wing } & $0.253 *$ & 0.154 \\
\hline & $(0.15)$ & $(0.13)$ \\
\hline \multirow[t]{2}{*}{ LargeSize*Right Wing } & $0.363 * *$ & 0.242 \\
\hline & $(0.17)$ & $(0.15)$ \\
\hline \multirow[t]{2}{*}{ Medium Beliefs } & & $0.538 * * *$ \\
\hline & & $(0.08)$ \\
\hline \multirow[t]{2}{*}{ High Beliefs } & & $0.617 * * *$ \\
\hline & & $(0.08)$ \\
\hline \multirow[t]{2}{*}{ Constant } & $0.824 * * *$ & $0.318 * * *$ \\
\hline & $(0.07)$ & $(0.10)$ \\
\hline Observations & 211 & 211 \\
\hline R-squared & 0.067 & 0.294 \\
\hline Adjusted R2 & 0.035 & 0.262 \\
\hline \multicolumn{3}{|c|}{$\begin{array}{l}\text { Notes: MedSize }=1 \text { if group size is set to } 7 \text {. LargeSize }=1 \text { if group size is set to } 25 . \text { Right } \\
\text { Wing }=1 \text { for subjects who would vote for the Center Party, the Christian Democrats, the } \\
\text { Liberals, the Moderate Party, or the Sweden Democrats. Older }(>23)=1 \text { for subjects older } \\
\text { than the median age of } 23 \text {. Medium Beliefs }=1 \text { for subjects who believed that around half } \\
\text { of their co-players cooperated. High Beliefs }=1 \text { for subjects who believed that all or almost } \\
\text { all of their co-players cooperated. Robust standard errors in parentheses. } \\
* * * p<0.01, * * p<0.05, * p<0.1\end{array}$} \\
\hline
\end{tabular}

First note that, in Model 1, the estimate for Right Wing is negative and statistically significant $(\mathrm{p}$-value $=0.003)$. The point estimate implies that leftists are 31 percentage points more likely to cooperate than rightists in the 3-person PD. However, in the treatments with medium and large group size, no significant difference between leftists and rightists is detected. Specifically, the coefficient for the Right Wing dummy is estimated to a mere -0.059 (p-value $=0.587$ )

\footnotetext{
${ }^{20}$ For SmallNeu, the alternatives were 0, 1, or 2 students. For $\mathrm{MedNeu}$, the alternatives were 0-2, 3-4, or 5-6 students. For LargeNeu, the alternatives were 0-8, 9-16, or 17-24 students.
} 
when the group size is 7 , and to 0.051 (p-value=0.699) when the group size is $25 .^{21}$ Indeed, when observing the interaction terms, which are positive and statistically significant, we learn that the left-right effect in the 3-person PD is significantly larger than the left-right effect in the 7- and 25-person PDs. ${ }^{22}$ In other words, the left-right effect on cooperation diminishes with the size of the decision group. This can easily be viewed in Figure 2, which depicts the estimated share of cooperating leftists and rightists in each treatment group when both control variables are set to their respective mean.

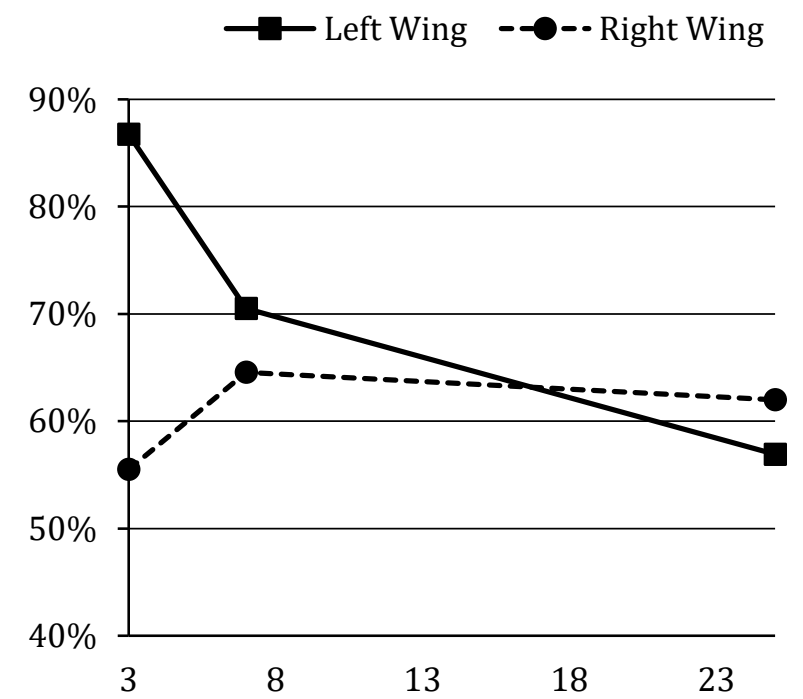

Figure 2. The estimated share of left-wing cooperators (solid line) and right-wing cooperators (dashed line) when the group size is set to 3 (SmallSize), 7 (MedSize), or 25 (LargeSize) and both covariates are held at their mean. The estimates are based on those obtained in Model 1, Table 2. The Y-axis is cut for improved visibility.

As we see in Figure 2, the share of cooperating leftists declines while the share of cooperating rightists is more stable. If it is the case that the cooperativeness among leftists declines with group size while rightists are unaffected, this explains why the difference in cooperation between the left and the right diminishes with group size. To analyze the issue further, view Model 1 in Table 2 again and note that the treatment dummies reflect the estimated treatment effects for leftists alone. The coefficient for MedSize implies that leftists are 16 percentage points less likely to cooperate when the group size is 7 as opposed to 3 (p-value=0.072). Likewise, leftists are 30 percentage points less likely to cooperate when the group size is 25 as opposed to 3 ( $\mathrm{p}$-value=0.002). Thus, there is a negative group size effect for leftists. However, for rightists, the estimates for both MedSize and LargeSize are positive, close to zero, and not

\footnotetext{
${ }^{21}$ To obtain the effect of Right Wing when the group size is 7 or 25, simply add the coefficient estimate for each interaction term to the estimate for Right Wing. In this manner, the effect when the group size is 7 is $-0.312+0.253$ $=-0.059$. The effect of being a rightist when the group size is 25 is $-0.312+0.363=0.051$.

${ }^{22}$ The p-values for MedSize*Right Wing and LargeSize*Right Wing are 0.095 and 0.031 , respectively.
} 
significant. ${ }^{23}$ Hence, I find no evidence in favor of a group size effect for rightists. In line with this, I find that the group size effect is significantly larger for leftists than for rightists (note the positive and significant interaction terms in Model 1, Table 2). Thus, the behavioral response to an increased group size differs between leftists and rightists.

To explain these findings, I include the categorical variable Beliefs as a predictor variable in Model 2. As we can see in Table 2, the point estimate of Right Wing decreases in absolute magnitude by about a third of its value in Model 1. This suggests that Beliefs is to some extent mediating the left-right effect. However, note that the estimate is still significantly different from zero, which means that leftists cooperate more than rightists in 3-person PDs independent of Beliefs. Something other than deviating beliefs about others' behavior is causing leftists to cooperate more than rightists when they are in a group of three people. Moreover, note that the estimated coefficients for both the treatments and the interaction terms are substantially reduced in size when controlling for Beliefs. In fact, the coefficient for MedSize and both interaction terms lose their significance. This implies that beliefs about others' behavior mediate the negative group size effect for leftists as well as the heterogeneity of the group size effect.

\subsection{GAL-TAN}

To delve deeper into the role of political ideology for cooperation, the subjects are divided into three political preference groups based on the GAL-TAN scale in this subsection. The GAL-TAN scale is an 11-point scale coined by Hooghe et al. (2002) that captures the social left-right dimension ranging from 0 (green/alternative/libertarian; GAL) to 5 (center; CEN) to 10 (traditional/authoritarian/nationalist; TAN). For a detailed description, see Bakker et al. (2012). To position the participants along the GAL-TAN scale, I employ the mean party positioning data supplied by the Chapel Hill Expert Survey (CHES) for year 2017 (Polk et al. 2017). I then group the parties into three categories: GAL, CEN, and TAN. The following cutoffs are used to obtain fairly balanced sample sizes:

- Categorized as GAL: $0 \leq$ mean GAL-TAN value $\leq 2$

- Categorized as CEN: $2<$ mean GAL-TAN value $\leq 5$

- Categorized as TAN: $5<$ mean GAL-TAN value $\leq 10$

\footnotetext{
${ }^{23}$ To obtain the treatment estimates for rightists alone, add each treatment effect for leftists to the corresponding interaction term. Thus, for rightists, the effect of MedSize is $-0.162+0.253=0.091$, while the effect of LargeSize $-0.298+0.363=0.064$
} 
Thus, the parties are categorized as follows:

- GAL: the Feminist Initiative, the Green Party, and the Left Party.

- CEN: the Center Party, the Liberals, and the Social Democratic Party.

- TAN: the Christian Democrats, the Moderate Party, and the Sweden Democrats.

\subsubsection{GAL-TAN Regression Analysis}

Table 3 displays a reproduction of Table 2 where a political ideology variable based on the GAL-TAN scale is used instead of the traditional left-right division. The base in both Model 1 and Model 2 consists of people affiliated with GAL parties in the 3-person version of the NPD. In the first model, we can observe that people with more traditional/authoritarian/nationalistic preferences cooperate significantly less than people with more green/alternative/libertarian preferences when the group size is set to 3. Specifically, people affiliated with TAN parties are 24 percentage points less likely to cooperate than their GAL party counterparts (pvalue $=0.048$ ). Interestingly, this difference is almost as large as the point estimated difference in cooperation between people affiliated with GAL parties and those affiliated with CEN parties $(-0.209 ; \mathrm{p}$-value $=0.106)$, while the estimated difference between people affiliated with CEN parties and those affiliated with TAN parties is close to zero $(-0.032 ; \mathrm{p}$-value $=0.828)$. This implies that people at the center and to the right of the social left-right scale act fairly similarly, while people to the left are the ones that stand out. However, this is only the case in the 3-person version. When the group size is increased to 7 and 25 , no significant differences between the political categories are detected, in line with the findings in subsection 4.2, where a dichotomous left-right classification is used. 
Table 3

Linear probability model regression. Dependent variable: Cooperation=1 for subjects who chose Option A. Base: GAL affiliated voters in 3-person PD, i.e., people who would vote for the Feminist Initiative, the Green Party, or the Left Party.

\begin{tabular}{|c|c|c|}
\hline VARIABLES & Model 1 & Model 2 \\
\hline MedSize & $\begin{array}{l}-0.092 \\
(0.11)\end{array}$ & $\begin{array}{l}-0.026 \\
(0.10)\end{array}$ \\
\hline LargeSize & $\begin{array}{l}-0.307 * * * \\
(0.12)\end{array}$ & $\begin{array}{l}-0.198^{*} \\
(0.10)\end{array}$ \\
\hline CEN & $\begin{array}{l}-0.209 \\
(0.13)\end{array}$ & $\begin{array}{l}-0.174 \\
(0.11)\end{array}$ \\
\hline TAN & $\begin{array}{l}-0.240 * * \\
(0.12)\end{array}$ & $\begin{array}{l}-0.191 * \\
(0.12)\end{array}$ \\
\hline Older $(>23)$ & $\begin{array}{l}0.131^{*} \\
(0.07)\end{array}$ & $\begin{array}{l}0.068 \\
(0.06)\end{array}$ \\
\hline Female & $\begin{array}{l}-0.044 \\
(0.07)\end{array}$ & $\begin{array}{l}-0.063 \\
(0.06)\end{array}$ \\
\hline MedSize*CEN & $\begin{array}{l}0.074 \\
(0.17)\end{array}$ & $\begin{array}{l}0.074 \\
(0.15)\end{array}$ \\
\hline LargeSize*CEN & $\begin{array}{l}0.320^{*} \\
(0.19)\end{array}$ & $\begin{array}{l}0.254 \\
(0.17)\end{array}$ \\
\hline MedSize*TAN & $\begin{array}{l}0.044 \\
(0.19)\end{array}$ & $\begin{array}{l}0.071 \\
(0.18)\end{array}$ \\
\hline LargeSize*TAN & $\begin{array}{l}0.193 \\
(0.20)\end{array}$ & $\begin{array}{l}0.165 \\
(0.18)\end{array}$ \\
\hline Medium Beliefs & & $\begin{array}{l}0.539 * * * \\
(0.08)\end{array}$ \\
\hline Low Beliefs & & $\begin{array}{l}0.625^{* * * *} \\
(0.08)\end{array}$ \\
\hline Constant & $\begin{array}{l}0.832 * * * \\
(0.08)\end{array}$ & $\begin{array}{l}0.337 * * * \\
(0.11)\end{array}$ \\
\hline Observations & 211 & 211 \\
\hline R-squared & 0.062 & 0.295 \\
\hline Adjusted R2 & 0.016 & 0.252 \\
\hline \multicolumn{3}{|c|}{$\begin{array}{l}\text { Notes: MedSize }=1 \text { if group size is set to } 7 \text {. LargeSize }=1 \text { if group size is set to } 25 . \text { CEN }=1 \text { for } \\
\text { subjects who would vote for the Center Party, the Liberals, or the Social Democratic Party. } \\
\text { TAN }=1 \text { for subjects who would vote for the Christian Democrats, the Moderate Party, or the } \\
\text { Sweden Democrats. Older }(>23)=1 \text { for subjects older than the median age of } 23 \text {. Medium } \\
\text { Beliefs }=1 \text { for subjects who believed around half of their co-players cooperated. High Be- } \\
\text { liefs }=1 \text { for subjects who believed that all or almost all of their co-players cooperated. Robust } \\
\text { standard errors in parentheses. } \\
* * * \mathrm{p}<0.01, * * \mathrm{p}<0.05, * \mathrm{p}<0.1\end{array}$} \\
\hline
\end{tabular}

Moreover, in Model 1 of Table 3, note that the coefficient for LargeSize is negative and statistically significant. The estimate implies that parties to the left on the GAL-TAN scale cooperate 31 percentage points less when the group size is 25 as opposed to 3 ( $p$-value $=0.009$ ). Thus, a negative group size effect is detected for people with green/alternative/libertarian views. No significant group size effect is found for people at the center or to the right on the GALTAN scale. In addition, the interaction term LargeSize ${ }^{*} C E N$ is positive and statistically significant ( $p$-value $=0.098$ ), meaning that the group size effect for people affiliated with GAL parties is significantly different from the group size effect for people affiliated with CEN parties. This 
can easily be viewed in Figure 2, which depicts the estimated share of cooperators in each treatment by position along the social left-right scale.

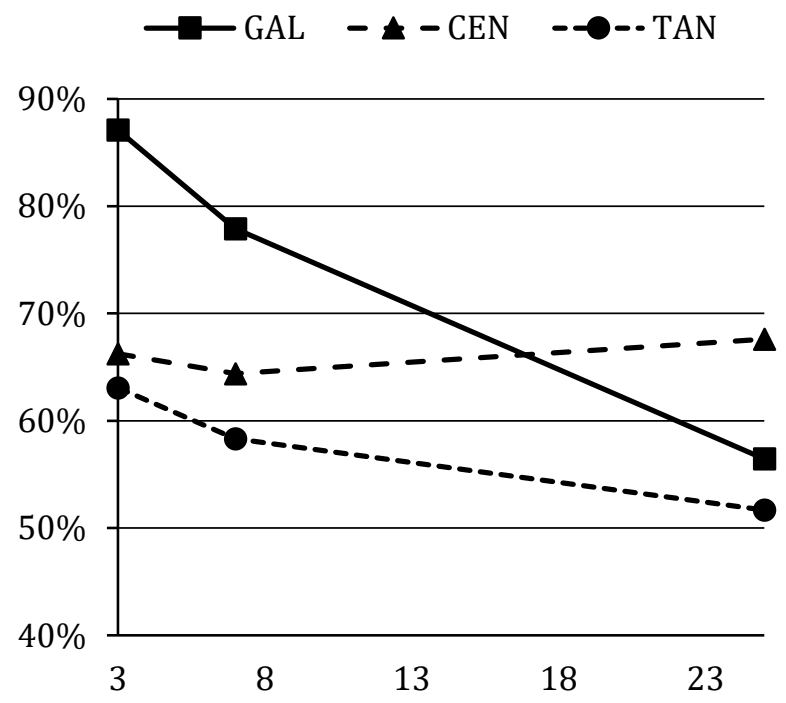

Figure 2. The estimated share of cooperators affiliated with GAL-parties (squares), CEN parties (triangles), and TAN parties (circles) when the group size is set to 3 (SmallSize), 7 (MedSize) or 25 (LargeSize) and both covariates are held at their mean. The estimates are based on those obtained in Model 1, Table 3. The Y-axis is cut for improved visibility.

To investigate the moderating effect of beliefs about others' behavior, the categorical variable Beliefs is included in Model 2 in Table 3. In line with the findings when a dichotomous left-right categorization is employed, the results suggest that belief about the cooperativeness of others is an important mediating factor, but that additional factors are at play as well. In particular, observe that the coefficients of interest drop in magnitude, but do not necessarily turn statistically non-significant.

\subsection{Robustness Checks}

In the main analysis of this paper, the subjects who reported completing the experiment in a random fashion were dropped. As a robustness check, I include these observations and reproduce the regressions of Table 2 (see the appendix). The sample size then increases from 211 to 227 students. The results are robust to including these additional students.

As an additional robustness check, I employ narrower categories of political attitude (see the appendix). In these regressions, the subjects affiliated with parties outside the traditional left-wing and right-wing blocks in Sweden are dropped (the Feminist Initiative and the Sweden Democrats). Thus, the left parties in this robustness check are the Green Party, the Left Party, and the Social Democratic Party, while the right parties are the Center Party, the Christian 
Democrats, the Liberals, and the Moderate Party. The results are in line with those presented in the main analysis.

Furthermore, since almost $25 \%$ of the experiment subjects did not know which party they would vote for and were thus dropped in the main analysis, Table 2 is reproduced using unsure voters as an additional political affiliation category (see the appendix) ${ }^{24}$ For leftists and rightists, the results are in line with those presented in the main analysis. Interestingly, the results of this robustness check suggest that unsure voters act similarly to rightists.

\section{Conclusions}

Cooperation is fundamental to human society. To facilitate cooperation, and thereby social progress, we need to understand the determinants of cooperation as well as the underlying mechanisms. This paper focused on one (possible) determinant that has received surprisingly little attention: political ideology. To strengthen the knowledge about this topic, I conducted an incentivized, one-shot N-person prisoner's dilemma experiment where the group size was set to 3,7 , or 25 .

I found that left-wing voters cooperate significantly more than right-wing voters in 3person PDs. This is a novel finding within the literature. Only one previous study has been conducted on the link between political ideology and cooperation in PDs. Balliet et al. (2018) conducted a 2-person PD in the U.S. and compared the choices made by Republicans and Democrats. However, the subjects were informed about the political affiliation of their co-player, meaning that they were not completely anonymous to each other. This experiment design could be the reason why Balliet et al. (2018) were unable to detect a difference in cooperation between Republicans and Democrats. On the other hand, it is possible that there indeed is no substantial link between political ideology and cooperation in the U.S., which is where Balliet et al. (2018) conducted their experiment. My results appear to be primarily driven by people of socialistic views, while people at the center and to the right of the political spectrum in Sweden act fairly similar. It is possible that the left side within American politics (Democrats) are located too far right on the spectrum to cause the differences observed in my experiment.

Moreover, the left-right effect found in the 3-person version of my experiment was not detected in the 7-person and 25-person versions. Instead, I found that the difference in cooperation between the left and the right significantly diminished as the group size grew, and that the reason for this diminishing left-right effect was a reduction in cooperation among leftists. As

\footnotetext{
${ }^{24}$ When unsure voters are included, only 31 participants $(9.7 \%)$ who did not want to disclose their political affiliation or who specified a party that was not on the list are excluded from the analysis.
} 
the group size was increased from 3 to 7 and 25, leftists cooperated significantly less. This means that a negative group size effect was present for leftists, which is in line with previous literature (Marwell \& Schmitt 1972; Kahan 1973; Hamburger et al. 1975; Bonacich et al. 1976; Fox \& Guyer 1977; Komorita \& Lapworth 1982; Grujić et al. 2012; Barcelo \& Capraro 2015; Bosch-Domènech \& Silvestre 2017). However, for rightists, the level of cooperation appears fairly stable across treatments and I found no evidence of a group size effect for people with right-wing views. Using regression analysis, I showed that the group size effect is in fact heterogeneous and varies with political affiliation, which is a novel finding in the literature. To the best of my knowledge, no previous attempts to study the heterogeneity of the group size effect have been made. Given the greater sensitivity to group size observed among leftists, to facilitate cooperation it might be advisable to exercise greater care when constructing decision groups if the population is predominately left wing as opposed to predominately right wing.

Since issues of importance to society usually involve a great number of actors, it would in the future be interesting to investigate whether political ideology continues to have a minor impact on cooperation as the group size grows beyond 25 members. Since I found that the diminishing left-right effect was driven by a negative group size effect among leftists, it is possible that leftists continue to cooperate less and less as the group size grows. Hence, for a large enough group, the left might even exhibit significantly less cooperative behavior than the right.

Moreover, I found that subjects' beliefs about the cooperativeness of their group members can to some extent explain these results, which is in line with previous studies that have found that beliefs play an important role for cooperation (e.g., Deutsch 1960; Dawes 1980; Messic \& Brewer 1983; Yamagishi 1986, 1988; Fischbacher et al. 2001; Ferrin et al. 2008). However, a large part remains unexplained. Further research is needed where additional factors, such as differences in cooperation preferences, are studied. See Fosgaard et al. (2019) for a suitable methodology. Unfortunately, in my experiment, no questions were asked to assess the subjects' cooperation preferences.

Furthermore, to delve deeper into the role of political ideology for cooperation, I reproduced the main analysis using a categorical variable based on the GAL-TAN scale. The parties were categorized as either GAL (green/alternative/libertarian), CEN (center), or TAN (traditional/authoritarian/nationalist). In this extension, we could see that people with views at the center or to the right on this social left-right scale act similarly to one another, while it is the ones to the left that stand out. Among those with more green/alternative/libertarian views, the cooperation rate starts off high but declines substantially with group size. 
A limitation of the results of this paper concerns their generalizability. As shown in the appendix, although the political affiliation composition in this experiment is not far from the actual result of the 2018 general election in Sweden (held 6 months after the experiment), the subject pool does not completely reflect the political views in Sweden, especially concerning the two least established parties (the Sweden Democrats is underrepresented and the Feminist Initiative is overrepresented in my experiment). Nevertheless, the results are robust to excluding these two parties from the analysis.

Moreover, the main analysis of this paper was based on participants who knew their political affiliation. However, almost $25 \%$ of the participants were not sure which party they would vote for. Thus, an analysis where unsure voters were treated as a political affiliation category was conducted. This analysis showed that unsure voters acted in a similar manner as rightists. 


\section{References}

Anderson, L. R., Mellor, J. M., Milyo, J., 2005. Do Liberals Play Nice? The Effects of Party and Political Ideology in Public Goods and Trust Games. In: Morgan, J. (Ed.) Advances in Applied Microeconomics, Vol. 13. Bingley: Emerald Group Publishing Limited, $107-$ 131.

Bakker, R., de Vries, C., Edwards, E., Hooghe, L., Jolly, S., Marks, G., Polk, J., Rovny, J., Steenbergen, M., Vachudova, M. A., 2015. Measuring party positions in Europe: The Chapel Hill expert survey trend file, 1999-2010. Party Politics, 21(1), 143-152.

Balliet, D., Parks, C., Joireman, J., 2009. Social Value Orientation and Cooperation in Social Dilemmas: A Meta-analysis. Group Processes \& Intergroup Relations, 12, 533-47.

Balliet, D., Tybur, J., Wu, J., Antonellis, C., Van Lange, P., 2018. Political Ideology, Trust, and Cooperation: In-group Favoritism among Republicans and Democrats during a US National Election. The Journal of Conflict Resolution, 62(4), 797-818.

Barcelo, H., Capraro, V., 2015. Group size effect on cooperation in one-shot social dilemmas. Scientific Reports, 5(1), 7937.

Bonacich, P., Shure, G. H., Kahan, J. P., Meeker, R. J., 1976. Cooperation and group size in the n-person prisoners' dilemma. Journal of Conflict Resolution, 20(4), 687-706.

Bosch-Domenech, A., Silvestre, J., 2017. The role of frames, numbers and risk in the frequency of cooperation. International Review of Economics, 64(3), 245-267.

Cappelen, A.W., Halvorsen, T., Sørensen, E.Ø., Tungodden, B., 2017. Face-saving or fairminded: What motivates moral behavior? Journal of the European Economic Association, 15(3), 540-557.

Dawes, R., 1980. Social Dilemmas. Annual Review of Psychology, 31(169).

Dawes, C.T., Johannesson, M., Lindqvist, E., Loewen, P.J., Ostling, R., Bonde, M., Priks, F., 2012. Generosity and political preferences. IFN Working paper.

Deutsch, M., 1960. Trust, trustworthiness, and the F scale. The Journal of Abnormal and Social Psychology, 61, 138-140.

Dreber, A., Ellingsen, T., Johannesson, M., Rand, D.G., 2012. Do people care about social context? Framing effects in dictator games. Experimental Economics, 16(3), 349-371.

Duffy, J., \& Xie, H., 2016. Group size and cooperation among strangers. Journal of Economic Behavior \& Organization, 126, 55-74. 
Eiser, J.R., Bhavnani, K.K., 1974. The effect of situational meaning on the behaviour of subjects in the Prisoner's Dilemma Game. European Journal of Social Psychology, 4(1), 9397.

Fehr, E., Schmidt, K., 1999. A theory of fairness, competition, and cooperation. Quarterly Journal of Economics, 114, 817-868.

Ferrin, D. L., Bligh, M. C., Kohles, J. C., 2008. It takes two to tango: An interdependence analysis of the spiraling of perceived trustworthiness and cooperation in interpersonal and intergroup relationships. Organizational Behavior and Human Decision Processes, 107, 161-178.

Fischbacher, U., Gächter, S., Fehr, E., 2001. Are people conditionally cooperative? Evidence from a public goods experiment. Economics letters, 71(3), 397-404.

Fisman, R., Jakiela, P., Kariv, S., 2017. Distributional preferences and political behavior. Journal of Public Economics, 155, 1-10.

Fosgaard, T. R., Hansen, L. G., Wengström, E., 2019. Cooperation, framing, and political attitudes. Journal of Economic Behavior \& Organization, 158, 416-427.

Fox, J., Guyer, M., 1977. Group size and others' strategy in an N-person game. Journal of Conflict Resolution, 21(2), 323-338.

Grujić, J., Eke, B., Cabrales, A., Cuesta, J.A., Sánchez, A., 2012. Three is a crowd in iterated prisoner's dilemmas: experimental evidence on reciprocal behavior. Scientific Reports, 2(638).

Hamburger, H., Guyer, M., Fox, J., 1975. Group size and cooperation. Journal of Conflict Resolution, 19(3), 503-531.

Heywood, A., 2015. Key Concepts in Politics and International Relations. $2^{\text {nd }}$ ed. London: MacMillan Education UK.

Hooghe, L., Marks, G., Wilson, C. J., 2002. Does left/right structure party positions on European integration?. Comparative political studies, 35(8), 965-989.

Kahan, J. P., 1973. Noninteraction in an anonymous three-person prisoner's dilemma game. Behavioral Science, 18(2), 124-127.

Kerschbamer, R., Muller, D., 2017. Social preferences and political attitudes: An online experiment on a large heterogeneous sample. Working Papers 2017-16, Faculty of Economics and Statistics, University of Innsbruck.

Kollock, P., 1998. Social Dilemmas: The Anatomy of Cooperation. Annual Review of Sociology, 24(1), 183-214. 
Komorita, S. S., Lapworth, C. W., 1982. Cooperative choice among individuals versus groups in an N-person dilemma situation. Journal of Personality and Social Psychology, 42(3), 487.

Marwell, G., Schmitt, D. R., 1972. Cooperation in a three-person Prisoner's Dilemma. Journal of Personality and Social Psychology, 21(3), 376-383.

Messick, D. M., Brewer, M. B., 1983. Solving social dilemmas: A review. In: Wheeler, L., Shaver, P. (Eds.). Review of Personality and Social Psychology. Vol. 4. Beverly Hills: Sage publications, 11-44.

Muller, D., 2017. The anatomy of distributional preferences with group identity (No. 2017-02), Working Papers in Economics and Statistics, University of Innsbruck.

Muller, D., Renes, S., 2017. Fairness views and political preferences: Evidence from a large online experiment (No. 2017-10), Working Papers in Economics and Statistics, University of Innsbruck.

Polk, J., Rovny, J., Bakker, R., Edwards, E., Hooghe, L., Jolly, S., Koedam, J., Kostelka, F., Marks, G., Schumacher, G., Steenbergen, M., Vachudova, M., Zilovic, M., 2017. Explaining the salience of anti-elitism and reducing political corruption for political parties in Europe with the 2014 Chapel Hill Expert Survey data. Research \& Politics, 4(1), 1-9.

Statistics Sweden. (2017). Data available for download at: Valutakurser, månadsgenomsnitt. https://www.scb.se/sv_/Hitta-statistik/Statistik-efter-amne/22678/Allmant/Sverigesekonomi/Aktuell-Pong/31243/EK0205/32234/ [Last Accessed 2018-04-21]

Thomsson, K.M., Vostroknutov, A., 2017. Small-world conservatives and rigid liberals: Attitudes towards sharing in self-proclaimed left and right. Journal of Economic Behavior and Organization, 135, 181-192

Van Lange, P., De Bruin, E., Otten, W., Joireman, J. 1997. Development of Prosocial, Individualistic, and Competitive Orientations: Theory and Preliminary Evidence. Journal of Personality and Social Psychology, 73, 733-46.

Van Lange, P., 1999. The Pursuit of Joint Outcomes and Equality in Outcomes: An Integrative Model of Social Value Orientation. Journal of Personality and Social Psychology, 77(2), $337-49$.

Yamagishi, T., 1986. The Provision of a Sanctioning System as a Public Good. Journal of Personality and Social Psychology, 51(1), 110-116.

Yamagishi, T., 1988. The provision of a sanctioning system in the United States and Japan. Social Psychology Quarterly, 51, 265-271. 


\section{Appendix}

This document provides supplementary materials for the paper "Experimental Evidence on Cooperation, Political Affiliation, and Group Size” by Ronja Helénsdotter.

\section{This document contains:}

1. A table presenting the main variables used in the analysis.

2. Additional tables with descriptive statistics of the main variables.

3. Table 2 of the main text using a narrower definition of the left and right wing categories. Specifically, subjects affiliated with the Feminist Initiative or the Sweden Democrats are dropped.

4. Table 2 of the main text using unsure voters as a political affiliation category.

5. Table 2 of the main text including subjects who answered the NPD at random. 


\section{Variables}

Table A1 displays an overview of the variables used in the main text.

Table A1

Variable overview.

\begin{tabular}{|c|c|c|}
\hline Name & Type & Description \\
\hline Cooperated & Dummy & $=1$ if chose to cooperate in the NPD. \\
\hline Treatment & Categorical & $\begin{array}{l}\text { Three categories. SmallSize }=1 \text { if in treatment with 3-person groups. } \\
\text { MedSize }=1 \text { if in treatment with 7-person groups. LargeSize }=1 \text { if in } \\
\text { treatment with } 25 \text {-person groups. }\end{array}$ \\
\hline Right Wing & Dummy & $\begin{array}{l}=1 \text { for subjects who would vote for the Center Party, the Christian } \\
\text { Democrats, the Liberal Party, the Moderate Party, or the Sweden } \\
\text { Democrats. Right Wing = } 0 \text { for subjects who would vote for the Fem- } \\
\text { inist Initiative, the Green Party, the Left Party, or the Social Demo- } \\
\text { cratic Party. }\end{array}$ \\
\hline Older $(>23)$ & Dummy & $=1$ for subjects older than the median age of 23 . \\
\hline Female & Dummy & $=1$ for females. \\
\hline Beliefs & Categorical & $\begin{array}{l}\text { Three categories (Low Beliefs, Medium Beliefs, High Beliefs). For all } \\
\text { treatments, there were three alternatives which correspond to having } \\
\text { low, medium or high beliefs concerning the number of others' who } \\
\text { cooperated in the NPD. For SmallSize, the alternatives were } 0 \text { stu- } \\
\text { dents, } 1 \text { student, or } 2 \text { students. For MedSize, the alternatives were } 0- \\
2 \text { students, } 3-4 \text { students, or } 5-6 \text { students. For LargeSize, the alterna- } \\
\text { tives were } 0-8 \text { students, } 9-16 \text { students, or } 17-24 \text { students. }\end{array}$ \\
\hline
\end{tabular}




\section{Descriptive statistics}

The experiment was executed by sending an email to the university email accounts of 2,173 undergraduate students at the University of Gothenburg in March 2018. On average, the participants earned 38.7 SEK, with median 38 SEK, which translate to approx. 4.7 and 4.6 USD in mean and median earnings, respectively. ${ }^{25}$ The sample size was set to 500 , but since 40 of these 500 participants reported answering at random, their answers are excluded from the main analysis. In addition, four participants are excluded as they in their open-format motivation provided rationales that are incompatible with the instructions, e.g. stated that she/he defected to ensure that nobody would be left with 0 SEK. Thus, their answers make it evident that they did not understand the instructions. Four other participants are excluded as they reported that they were economics students or no longer students. Additionally, one student participated in the experiment twice. Consequently, the second entry from this participant is excluded. Finally, the participants had the opportunity to choose "Other" when asked about their gender, and since only three participants chose this option, they are not treated as an individual category. Instead, these three observations are dropped. Hence, the experiment yielded 448 valid responses.

Since this paper focuses on the treatments in which only the group size varied, the observations in the fourth treatment, which is a community framed treatment, are dropped (130 students). Moreover, 107 students completed the entire experiment, but answered that they i) did not know their political affiliation; ii) did not want to divulge their affiliation; or iii) specified a party not included on the list presented to them. As these participants cannot easily be categorized as rightists or leftists, they are excluded from the analysis as well. Thus, the main analysis of this paper is based on a total of 211 Swedish students.

${ }^{25}$ Average for Mars, 2018, USD 1 = SEK 8.23 (Statistics Sweden 2017). 
Table A2 displays the political affiliation composition including those who answered "Don't know", "Don't want to answer", or "Other".

Table A2

Political affiliation composition (including Don't know, Don't want to answer, and Other).

\begin{tabular}{lccc}
\hline & Freq. & Perc. & Wing \\
\hline The Center Party & 25 & $7.9 \%$ & Right \\
The Christian Democrats & 5 & $1.6 \%$ & Right \\
The Feminist Initiative & 17 & $5.4 \%$ & Left \\
The Green Party & 22 & $6.9 \%$ & Left \\
The Left Party & 44 & $13.8 \%$ & Left \\
The Liberal Party & 6 & $1.9 \%$ & Right \\
The Moderate Party & 40 & $12.6 \%$ & Right \\
The Social Democratic Party & 40 & $12.6 \%$ & Left \\
The Sweden Democrats & 12 & $3.8 \%$ & Right \\
Don't know & 76 & $23.9 \%$ & - \\
Don't want to answer & 20 & $6.3 \%$ & - \\
Other & 11 & $3.5 \%$ & - \\
\hline Total & 318 & $100 \%$ & \\
\hline
\end{tabular}


Table A3 displays the political affiliation composition of the sample employed in the main analysis. In my sample, which is comprised of primarily young Swedes, parties on the far left are overrepresented compared to the entire Swedish population. The most underrepresented party is the nationalistic party called the Sweden Democrats (almost 18\% voted for the Sweden Democrats in the 2018 Election while only close to $6 \%$ of the subjects in my experiment claimed they would vote for the party).

\section{Table A3}

Political affiliation composition of the sample used in the main analysis.

\begin{tabular}{lcccc}
\hline & Freq. & Perc. & $\begin{array}{c}\text { Perc. in } 2018 \\
\text { Election* }\end{array}$ & Wing \\
\hline The Center Party & 25 & $11.8 \%$ & $8.7 \%$ & Right \\
The Christian Democrats & 5 & $2.4 \%$ & $6.4 \%$ & Right \\
The Feminist Initiative & 17 & $8.1 \%$ & $0.5 \%$ & Left \\
The Green Party & 22 & $10.4 \%$ & $4.5 \%$ & Left \\
The Left Party & 44 & $20.9 \%$ & $8.1 \%$ & Left \\
The Liberal Party & 6 & $2.8 \%$ & $5.5 \%$ & Right \\
The Moderate Party & 40 & $19.0 \%$ & $20.1 \%$ & Left \\
The Social Democratic Party & 40 & $19.0 \%$ & $28.6 \%$ & Right \\
The Sweden Democrats & 12 & $5.7 \%$ & $41.6 \%$ & $58.4 \%$ \\
\hline Left Wing & 123 & $58.3 \%$ & $100 \%$ & \\
Right Wing & 88 & $41.7 \%$ & $100 \%$ & \\
Total & 211 & & \\
\hline * Source: Political affiliation composition figures obtained from the Election Authority, 2018. [Official Decis- \\
ion]. Fördelning av mandat i riksdagen och fastställande av vilka kandidater som har valts till ledamöter och \\
ersättare. Number: 200 378253-18/98236. Available at: https://data.val.se/val/val2018/slutresultat/proto- \\
koll/protokoll_00R.pdf
\end{tabular}


Table A4 displays descriptive statistics of the main variables broken down by political affiliation and in total.

Table A4

Summary statistics of main variables by political affiliation. Left Wing column is for subjects who would vote for the Feminist Initiative, the Green Party, the Left Party, or the Social Democratic Party. Right Wing column is for subjects who would vote for the Center Party, the Christian Democrats, the Liberal Party, the Moderate Party, or the Sweden Democrats.

\begin{tabular}{|c|c|c|c|}
\hline & Left Wing & Right Wing & Total \\
\hline \multicolumn{4}{|l|}{ Treatment } \\
\hline SmallSize & $32.5 \%$ & $35.2 \%$ & $33.7 \%$ \\
\hline MedSize & $34.2 \%$ & $36.4 \%$ & $35.1 \%$ \\
\hline LargeSize & $33.3 \%$ & $28.4 \%$ & $31.3 \%$ \\
\hline Older (>23) & $51.2 \%$ & $44.3 \%$ & $48.3 \%$ \\
\hline Female & $59.3 \%$ & $53.4 \%$ & $56.9 \%$ \\
\hline \multicolumn{4}{|l|}{ Beliefs } \\
\hline High Beliefs & $36.6 \%$ & $29.6 \%$ & $33.7 \%$ \\
\hline Medium Beliefs & $45.5 \%$ & $47.7 \%$ & $46.5 \%$ \\
\hline Low Beliefs & $17.9 \%$ & $22.7 \%$ & $19.9 \%$ \\
\hline Obs. & 123 & 88 & 211 \\
\hline \multicolumn{4}{|c|}{$\begin{array}{l}\text { Notes: SmallSize }=1 \text { if group size is set to } 3 . \text { MedSize }=1 \text { if group size is set to } 7 \\
\text { LargeSize }=1 \text { if group size is set to } 25 . \text { Older }(>23)=1 \text { for subjects older than the median } \\
\text { age of } 23 \text {. High Beliefs }=1 \text { for subjects who believed all or almost all of their co-players } \\
\text { cooperated. Medium Beliefs }=1 \text { for subjects who believed around half of their co-players } \\
\text { cooperated. Low Beliefs }=1 \text { for subjects who believed none or few of their co-players } \\
\text { cooperated. }\end{array}$} \\
\hline
\end{tabular}




\section{Narrower political affiliation categories}

Table A5 reproduces Table 2 of the main text using narrower grouping of the left and the right.

Now, Right Wing=1 for subjects who would vote for the Center Party, the Christian Democrats, the Liberal Party, or the Moderate Party. Right Wing=0 for subjects who would vote for the Green Party, the Left Party, or the Social Democratic Party.

\section{Table A5}

Linear probability model regression with narrower political affiliation categories. Dependent variable: Cooperation=1 for subjects who chose Option A. Base: leftists in 3-person PD, i.e., people who would vote for the Green Party, the Left Party, or the Social Democratic Party.

\begin{tabular}{|c|c|c|}
\hline VARIABLES & Model 1 & Model 2 \\
\hline MedSize & $\begin{array}{l}-0.207 * * \\
(0.10)\end{array}$ & $\begin{array}{l}-0.058 \\
(0.09)\end{array}$ \\
\hline LargeSize & $\begin{array}{l}-0.253 * * \\
(0.10)\end{array}$ & $\begin{array}{l}-0.116 \\
(0.09)\end{array}$ \\
\hline Right Wing & $\begin{array}{l}-0.331 \text { *** } \\
(0.12)\end{array}$ & $\begin{array}{l}-0.199^{*} \\
(0.11)\end{array}$ \\
\hline Older (>23) & $\begin{array}{l}0.130 * \\
(0.07)\end{array}$ & $\begin{array}{l}0.070 \\
(0.06)\end{array}$ \\
\hline Female & $\begin{array}{l}-0.054 \\
(0.07)\end{array}$ & $\begin{array}{l}-0.071 \\
(0.06)\end{array}$ \\
\hline MedSize*Right Wing & $\begin{array}{l}0.314^{*} \\
(0.17)\end{array}$ & $\begin{array}{l}0.115 \\
(0.15)\end{array}$ \\
\hline LargeSize*Right Wing & $\begin{array}{l}0.374 * * \\
(0.18)\end{array}$ & $\begin{array}{l}0.203 \\
(0.16)\end{array}$ \\
\hline Medium Beliefs & & $\begin{array}{l}0.598 * * * \\
(0.08)\end{array}$ \\
\hline High Beliefs & & $\begin{array}{l}0.611 * * * \\
(0.08)\end{array}$ \\
\hline Constant & $\begin{array}{l}0.836 * * * \\
(0.08)\end{array}$ & $\begin{array}{l}0.302 * * * \\
(0.10)\end{array}$ \\
\hline Observations & 182 & 182 \\
\hline R-squared & 0.064 & 0.325 \\
\hline Adjusted R2 & 0.026 & 0.290 \\
\hline \multicolumn{3}{|c|}{$\begin{array}{l}\text { Notes: MedSize }=1 \text { if group size is set to } 7 \text {. LargeSize }=1 \text { if group size is set to } 25 . \text { Right } \\
\text { Wing }=1 \text { for subjects who would vote for the Center Party, the Christian Democrats, the } \\
\text { Liberal Party, or the Moderate Party. Older }(>23)=1 \text { for subjects older than the median age } \\
\text { of } 23 \text {. Medium Beliefs }=1 \text { for subjects who believed around half of their co-players cooper- } \\
\text { ated. High Beliefs }=1 \text { for subjects who believed all or almost all of their co-players cooper- } \\
\text { ated. Robust standard errors in parentheses. } \\
* * * \mathrm{p}<0.01, * * \mathrm{p}<0.05, * \mathrm{p}<0.1\end{array}$} \\
\hline
\end{tabular}




\section{Unsure voters as political affiliation category}

Table A6 below reproduces Table 2 of the main text using unsure voters as a political affiliation category in addition to leftists and rightists.

\section{Table A6}

Linear probability model regression with three political affiliation categories. Dependent variable: Cooperation $=1$ for subjects who chose Option A. Base: leftists in 3-person PD, i.e., people who would vote for the Feminist Initiative, the Green Party, the Left Party, or the Social Democratic Party.

\begin{tabular}{|c|c|c|}
\hline VARIABLES & Model 1 & Model 2 \\
\hline MedSize & $\begin{array}{l}-0.155^{*} \\
(0.09)\end{array}$ & $\begin{array}{l}-0.052 \\
(0.08)\end{array}$ \\
\hline LargeSize & $\begin{array}{l}-0.290 * * * \\
(0.10)\end{array}$ & $\begin{array}{l}-0.170 * \\
(0.09)\end{array}$ \\
\hline Right Wing & $\begin{array}{l}-0.307 * * * \\
(0.11)\end{array}$ & $\begin{array}{l}-0.212 * * \\
(0.10)\end{array}$ \\
\hline Unsure voter & $\begin{array}{l}-0.196^{*} \\
(0.10)\end{array}$ & $\begin{array}{l}-0.125 \\
(0.09)\end{array}$ \\
\hline Older $(>23)$ & $\begin{array}{l}0.105^{*} \\
(0.06)\end{array}$ & $\begin{array}{l}0.081 * \\
(0.05)\end{array}$ \\
\hline Female & $\begin{array}{l}-0.007 \\
(0.06)\end{array}$ & $\begin{array}{l}-0.051 \\
(0.05)\end{array}$ \\
\hline MedSize*Right Wing & $\begin{array}{l}0.248 \\
(0.15)\end{array}$ & $\begin{array}{l}0.160 \\
(0.13)\end{array}$ \\
\hline LargeSize*Right Wing & $\begin{array}{l}0.352 * * \\
(0.17)\end{array}$ & $\begin{array}{l}0.246^{*} \\
(0.15)\end{array}$ \\
\hline MedSize *Unsure voter & $\begin{array}{l}0.119 \\
(0.16)\end{array}$ & $\begin{array}{l}0.058 \\
(0.14)\end{array}$ \\
\hline LargeSize*Unsure voter & $\begin{array}{l}0.271 \\
(0.17)\end{array}$ & $\begin{array}{l}0.218 \\
(0.15)\end{array}$ \\
\hline Medium Beliefs & & $\begin{array}{l}0.519 * * * \\
(0.07)\end{array}$ \\
\hline High Beliefs & & $\begin{array}{l}0.645^{* * * *} \\
(0.07)\end{array}$ \\
\hline Constant & $\begin{array}{l}0.815 * * * \\
(0.07)\end{array}$ & $\begin{array}{l}0.306 * * * \\
(0.09)\end{array}$ \\
\hline Observations & 287 & 287 \\
\hline R-squared & 0.047 & 0.291 \\
\hline Adjusted R2 & 0.013 & 0.260 \\
\hline \multicolumn{3}{|c|}{$\begin{array}{l}\text { Notes: MedSize }=1 \text { if group size is set to } 7 \text {. LargeSize }=1 \text { if group size is set to } 25 \text {. Right Wing }=1 \\
\text { for subjects who would vote for the Center Party, the Christian Democrats, the Liberal Party, } \\
\text { the Moderate Party, or the Sweden Democrats. Unsure voter }=1 \text { for subject who did not know } \\
\text { which party they would vote for. Older }(>23)=1 \text { for subjects older than the median age of } 23 \text {. } \\
\text { Medium Beliefs }=1 \text { for subjects who believed around half of their co-players cooperated. High } \\
\text { Beliefs }=1 \text { for subjects who believed all or almost all of their co-players cooperated. Robust } \\
\text { standard errors in parentheses. }\end{array}$} \\
\hline$* * * \mathrm{p}<0.01, * * \mathrm{p}<0.05, *$ & & \\
\hline
\end{tabular}




\section{Including subjects who answered at random}

Table A7 below reproduces Table 2 of the main text including subjects who answered that they made their decision in the NPD at random.

\section{Table A7}

Linear probability model regression including subjects who made their decision in the NPD at random. Dependent variable: Cooperation $=1$ for subjects who chose Option A. Base: leftists in 3-person PD, i.e. people who would vote for the Feminist Initiative, the Green Party, the Left Party, or the Social Democratic Party.

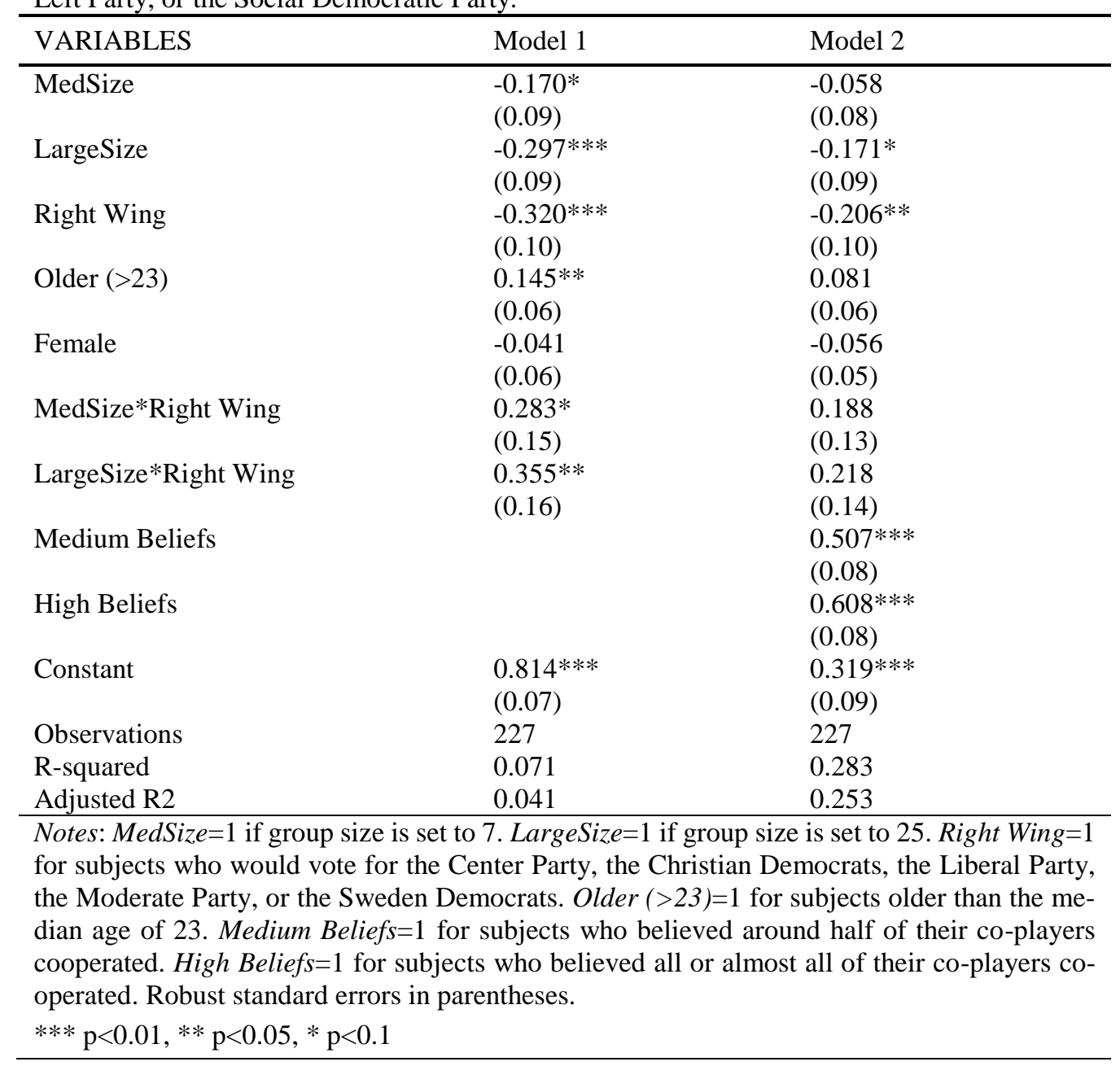




\section{Instructions}

This document provides the instructions given to participants of the N-person prisoner's dilemma experiment on which the paper "Experimental Evidence on Cooperation, Political Affiliation, and Group Size” by Ronja Helénsdotter is based on.

\section{This document contains:}

6. English translation of the email invitation.

7. Screenshot of the email invitation in the original language (Swedish).

8. English translation of the instructions.

9. Screenshot of the instructions in the original language (Swedish). 


\section{Email invitation (translated)}

The translated version of the email invitation sent to the students is given below.

Hi [field of education] student,

If you complete my decision experiment that takes about 10 minutes you can get up to $70 \mathrm{kr}$. The experiment is part of my master thesis in economics.

It is of course completely voluntary to participate, but at the same time you cannot be replaced by somebody else - your answers are important! In a scientific survey, it is important that people of different views participate.

Financing has been obtained from Centre for Collective Action Research at University of Gothenburg.

Your answers will be anonymized before processing to assure anonymity.

To participate, just follow the link:

[Link given]

Thank you for participating!

Ronja Sundborg

Supervisor: Elina Lampi 


\section{Email invitation (screenshot)}

Figure 2.1. Screenshot of email invitation.

Hej blivande fysiker,

Om du genomför mitt beslutsexperiment som tar ca 10 minuter kan du få upp till $70 \mathrm{kr}$. Experimentet är en del av min masteruppsats i nationalekonomi.

Det är naturligtvis helt frivilligt att vara med, men samtidigt kan du inte ersättas av någon annan - dina svar är viktiga! I en vetenskaplig undersökning är det viktigt att människor med olika uppfattningar deltar.

Finansiering har erhållits från Centrum för studier av kollektivt handlande vid Göteborgs Universitet.

Dina svar kommer avidentifieras före bearbetning för att säkerställa anonymitet.

Det är bara att följa länken för att vara med:

https://form.jotformeu.com/Beslutsexperiment/experiment

Stort tack för att du är med!

Ronja Sundborg

Handledare: Elina Lampi 


\section{Instructions (translated)}

The English version of the experiment instructions are given below.

Welcome to this decision experiment. If you complete the whole experiment, you can receive up to 70 kronor depending on your choices and the choices of others. You can choose to be paid via SWISH or collect your money in cash at the School of Business, Economics and Law. Details regarding payment are provided at the end of the experiment.

The experiment takes about 10 minutes to complete and consists of four parts.

It is important that you do not talk to anybody during the experiment and that you do not discuss the experiment with other students after you are done.

Are you born on an even/uneven day in an even/uneven month? Example: If you are born on April 15, you choose the option "Uneven day and even month".

- Even day and even month

$\circ$ Uneven day and even month

○ Even day and uneven month

○ Uneven day and uneven month

*Next page*

For participants in the treatment SmallSize, the following version of part 1 was shown.

\section{Part 1: The dilemma}

Below are the instructions to the dilemma presented.

$* * * * * * * * * * * * * * * * * * * * * * * * * * * * * * * * * * * * * * *$

A computer chooses two other students at random so that you make up a group of three students together. The other students get exactly the same instructions as you. Neither you nor the other students will learn anything about each other at any point in time.

You start the dilemma with 16 kronor and must choose Option A or B. If you choose Option A, you lose the 16 kronor while the other students get 24 kronor each. If you choose Option B, you keep the 16 kronor while the other students get nothing. Remember that all students face the 
same decision, which means that the amount of money each student exits the dilemma with depends on the choices of all students.

Below, you see some examples of possible outcomes.

Dilemma examples:

- If everybody chooses $\mathrm{A}$, the dilemma is ended with everybody getting $\mathbf{4 8}$ kronor each.

- If everybody chooses B, the dilemma is ended with everybody getting $\mathbf{1 6}$ kronor each.

- If you choose A and all the other students choose B, the dilemma is ended with you getting $\mathbf{0}$ kronor and the other students getting $\mathbf{4 0}$ kronor

- If you choose B and all the other students choose A, the dilemma is ended with you getting 64 kronor and the other students getting $\mathbf{2 4}$ kronor

$* * * * * * * * * * * * * * * * * * * * * * * * * * * * * * * * * * * * * * *$

If you wish to see all possible outcomes, you can click on "Open table" below.

Figure 3.1. The table over possible outcomes that was shown when the participants clicked the "Open table" button.

\begin{tabular}{|c|c|c|c|c|}
\hline \multirow[b]{2}{*}{$\begin{array}{l}\text { Number of others } \\
\text { that choose } A\end{array}$} & \multicolumn{2}{|c|}{ IF YOU CHOOSE A } & \multicolumn{2}{|c|}{ IF YOU CHOOSE B } \\
\hline & $\begin{array}{l}\text { Those that } \\
\text { choose A get }\end{array}$ & $\begin{array}{l}\text { Those that } \\
\text { choose B get }\end{array}$ & $\begin{array}{l}\text { Those that } \\
\text { choose A get }\end{array}$ & $\begin{array}{l}\text { Those that } \\
\text { choose B get }\end{array}$ \\
\hline 0 participants & $0 \mathrm{kr}$ & $40 \mathrm{kr}$ & - & $16 \mathrm{kr}$ \\
\hline 1 participants & $24 \mathrm{kr}$ & $64 \mathrm{kr}$ & $0 \mathrm{kr}$ & $40 \mathrm{kr}$ \\
\hline 2 participants & $48 \mathrm{kr}$ & & $24 \mathrm{kr}$ & $64 \mathrm{kr}$ \\
\hline
\end{tabular}

\section{What option do you choose in the dilemma?}

○ Option A

○ Option B

For participants in the treatment MedSize, the following version of part 1 was shown.

\section{Part 1: The dilemma}

Below are the instructions to the dilemma presented.

$* * * * * * * * * * * * * * * * * * * * * * * * * * * * * * * * * * * * * * *$

A computer chooses six other students at random so that you make up a group of seven students together. The other students get exactly the same instructions as you. Neither you nor the other students will learn anything about each other at any point in time. 
You start the dilemma with 16 kronor and must choose Option A or B. If you choose Option A, you lose the 16 kronor while the other students get 8 kronor each. If you choose Option B, you keep the 16 kronor while the other students get nothing. Remember that all students face the same decision, which means that the amount of money each student exits the dilemma with depends on the choices of all students.

Below, you see some examples of possible outcomes.

Dilemma examples:

- If everybody chooses $\mathrm{A}$, the dilemma is ended with everybody getting $\mathbf{4 8}$ kronor each.

- If everybody chooses B, the dilemma is ended with everybody getting $\mathbf{1 6}$ kronor each.

- If you choose A and all the other students choose B, the dilemma is ended with you getting $\mathbf{0}$ kronor and the other students getting $\mathbf{2 4}$ kronor

- If you choose B and all the other students choose A, the dilemma is ended with you getting 64 kronor and the other students getting $\mathbf{4 0}$ kronor

$* * * * * * * * * * * * * * * * * * * * * * * * * * * * * * * * * * * * * * * *$

If you wish to see all possible outcomes, you can click on "Open table" below.

Figure 3.2. The table over possible outcomes that was shown when the participants clicked the "Open table" button.

\begin{tabular}{|c|c|c|c|c|}
\hline \multirow[b]{2}{*}{$\begin{array}{l}\text { Number of others } \\
\text { that choose } A\end{array}$} & \multicolumn{2}{|c|}{ IF YOU CHOOSE A } & \multicolumn{2}{|c|}{ IF YOU CHOOSE B } \\
\hline & \begin{tabular}{|l} 
Those that \\
choose A get
\end{tabular} & $\begin{array}{l}\text { Those that } \\
\text { choose B get }\end{array}$ & $\begin{array}{l}\text { Those that } \\
\text { choose A get }\end{array}$ & $\begin{array}{l}\text { Those that } \\
\text { choose B get }\end{array}$ \\
\hline 0 participants & $0 \mathrm{kr}$ & $24 \mathrm{kr}$ & - & $16 \mathrm{kr}$ \\
\hline 1 participants & $8 \mathrm{kr}$ & $32 \mathrm{kr}$ & $0 \mathrm{kr}$ & $24 \mathrm{kr}$ \\
\hline 2 participants & $16 \mathrm{kr}$ & $40 \mathrm{kr}$ & $8 \mathrm{kr}$ & $32 \mathrm{kr}$ \\
\hline 3 participants & $24 \mathrm{kr}$ & $48 \mathrm{kr}$ & $16 \mathrm{kr}$ & $40 \mathrm{kr}$ \\
\hline 4 participants & $32 \mathrm{kr}$ & $56 \mathrm{kr}$ & $24 \mathrm{kr}$ & $48 \mathrm{kr}$ \\
\hline 5 participants & $40 \mathrm{kr}$ & $64 \mathrm{kr}$ & $32 \mathrm{kr}$ & $56 \mathrm{kr}$ \\
\hline 6 participants & $48 \mathrm{kr}-$ & & $40 \mathrm{kr}$ & $64 \mathrm{kr}$ \\
\hline
\end{tabular}

\section{What option do you choose in the dilemma?}

○ Option A

○ Option B

For participants in the treatment LargeSize, the following version of part 1 was shown. 


\section{Part 1: The dilemma}

Below are the instructions to the dilemma presented.

$* * * * * * * * * * * * * * * * * * * * * * * * * * * * * * * * * * * * * * *$

A computer chooses twenty-four other students at random so that you make up a group of twenty-five students together. The other students get exactly the same instructions as you. Neither you nor the other students will learn anything about each other at any point in time.

You start the dilemma with 16 kronor and must choose Option A or B. If you choose Option A, you lose the 16 kronor while the other students get 2 kronor each. If you choose Option B, you keep the 16 kronor while the other students get nothing. Remember that all students face the same decision, which means that the amount of money each student exits the dilemma with depends on the choices of all students.

Below, you see some examples of possible outcomes.

Dilemma examples:

- If everybody chooses A, the dilemma is ended with everybody getting $\mathbf{4 8}$ kronor each.

- If everybody chooses $\mathrm{B}$, the dilemma is ended with everybody getting $\mathbf{1 6}$ kronor each.

- If you choose A and all the other students choose B, the dilemma is ended with you getting $\mathbf{0}$ kronor and the other students getting 18 kronor

- If you choose B and all the other students choose A, the dilemma is ended with you getting 64 kronor and the other students getting 46 kronor

$* * * * * * * * * * * * * * * * * * * * * * * * * * * * * * * * * * * * * * * *$

If you wish to see all possible outcomes, you can click on "Open table" below.

Figure 3.3. The table over possible outcomes that was shown when the participants clicked the "Open table" button. 


\begin{tabular}{|c|c|c|c|c|}
\hline \multirow[b]{2}{*}{$\begin{array}{l}\text { Number of others } \\
\text { that choose A }\end{array}$} & \multicolumn{2}{|c|}{ IF YOU CHOOSE A } & \multicolumn{2}{|c|}{ IF YOU CHOOSE B } \\
\hline & $\begin{array}{l}\text { Those that } \\
\text { choose A get }\end{array}$ & $\begin{array}{l}\text { Those that } \\
\text { choose B get }\end{array}$ & $\begin{array}{l}\text { Those that } \\
\text { choose A get }\end{array}$ & $\begin{array}{l}\text { Those that } \\
\text { choose B get }\end{array}$ \\
\hline 0 participants & $0 \mathrm{kr}$ & $18 \mathrm{kr}$ & - & $16 \mathrm{kr}$ \\
\hline 1 participants & $2 \mathrm{kr}$ & $20 \mathrm{kr}$ & $0 \mathrm{kr}$ & $18 \mathrm{kr}$ \\
\hline 2 participants & $4 \mathrm{kr}$ & $22 \mathrm{kr}$ & $2 \mathrm{kr}$ & $20 \mathrm{kr}$ \\
\hline 3 participants & $6 \mathrm{kr}$ & $24 \mathrm{kr}$ & $4 \mathrm{kr}$ & $22 \mathrm{kr}$ \\
\hline 4 participants & $8 \mathrm{kr}$ & $26 \mathrm{kr}$ & $6 \mathrm{kr}$ & $24 \mathrm{kr}$ \\
\hline 5 participants & $10 \mathrm{kr}$ & $28 \mathrm{kr}$ & $8 \mathrm{kr}$ & $26 \mathrm{kr}$ \\
\hline 6 participants & $12 \mathrm{kr}$ & $30 \mathrm{kr}$ & $10 \mathrm{kr}$ & $28 \mathrm{kr}$ \\
\hline 7 participants & $14 \mathrm{kr}$ & $32 \mathrm{kr}$ & $12 \mathrm{kr}$ & $30 \mathrm{kr}$ \\
\hline 8 participants & $16 \mathrm{kr}$ & $34 \mathrm{kr}$ & $14 \mathrm{kr}$ & $32 \mathrm{kr}$ \\
\hline 9 participants & $18 \mathrm{kr}$ & $36 \mathrm{kr}$ & $16 \mathrm{kr}$ & $34 \mathrm{kr}$ \\
\hline 10 participants & $20 \mathrm{kr}$ & $38 \mathrm{kr}$ & $18 \mathrm{kr}$ & $36 \mathrm{kr}$ \\
\hline 11 participants & $22 \mathrm{kr}$ & $40 \mathrm{kr}$ & $20 \mathrm{kr}$ & $38 \mathrm{kr}$ \\
\hline 12 participants & $24 \mathrm{kr}$ & $42 \mathrm{kr}$ & $22 \mathrm{kr}$ & $40 \mathrm{kr}$ \\
\hline 13 participants & $26 \mathrm{kr}$ & $44 \mathrm{kr}$ & $24 \mathrm{kr}$ & $42 \mathrm{kr}$ \\
\hline 14 participants & $28 \mathrm{kr}$ & $46 \mathrm{kr}$ & $26 \mathrm{kr}$ & $44 \mathrm{kr}$ \\
\hline 15 participants & $30 \mathrm{kr}$ & $48 \mathrm{kr}$ & $28 \mathrm{kr}$ & $46 \mathrm{kr}$ \\
\hline 16 participants & $32 \mathrm{kr}$ & $50 \mathrm{kr}$ & $30 \mathrm{kr}$ & $48 \mathrm{kr}$ \\
\hline 17 participants & $34 \mathrm{kr}$ & $52 \mathrm{kr}$ & $32 \mathrm{kr}$ & $50 \mathrm{kr}$ \\
\hline 18 participants & $36 \mathrm{kr}$ & $54 \mathrm{kr}$ & $34 \mathrm{kr}$ & $52 \mathrm{kr}$ \\
\hline 19 participants & $38 \mathrm{kr}$ & $56 \mathrm{kr}$ & $36 \mathrm{kr}$ & $54 \mathrm{kr}$ \\
\hline 20 participants & $40 \mathrm{kr}$ & $58 \mathrm{kr}$ & $38 \mathrm{kr}$ & $56 \mathrm{kr}$ \\
\hline 21 participants & $42 \mathrm{kr}$ & $60 \mathrm{kr}$ & $40 \mathrm{kr}$ & $58 \mathrm{kr}$ \\
\hline 22 participants & $44 \mathrm{kr}$ & $62 \mathrm{kr}$ & $42 \mathrm{kr}$ & $60 \mathrm{kr}$ \\
\hline 23 participants & $46 \mathrm{kr}$ & $64 \mathrm{kr}$ & $44 \mathrm{kr}$ & $62 \mathrm{kr}$ \\
\hline 24 participants & $48 \mathrm{kr}$ & - & $46 \mathrm{kr}$ & $64 \mathrm{kr}$ \\
\hline
\end{tabular}

\section{What option do you choose in the dilemma?}

○ Option A

○ Option B

*Next page*

\section{Part 2(1): Motivation}

\section{Did you choose $\mathrm{A}(\mathrm{B})$ at random?}

- No

- Yes

If the participant chose "No", she/he moved on to part 2(2) on the next page. Otherwise, she/he moved straight on to part 3.

\section{Part 2(2): Motivation}

Below, a few suggested motivations are presented. Please choose those alternatives that you think best explain why you chose $A(B)$ in the dilemma. You can choose at least one and at most three alternatives. 
The following statements were randomized and only visible to participants who chose A.

I chose A because it is the choice I believe most other students in my group made

I chose A because it leads to the group getting most money in total

I chose A because I consider it to be the fair choice

I chose A because I care about others

I chose A because it feels good to help others

I chose A because I think that it is the ethically right thing to do

I chose A because I think that this choice is consistent with social norms

I chose A because it is the choice that I'd like everybody to make in this situation

I chose A for another reason

The following statements were randomized and only visible to participants who chose $B$.

I chose B because it is the choice I believe most other students in my group made

I chose $\mathrm{B}$ because it is the most profitable choice for me

I chose $\mathrm{B}$ because I want to avoid getting 0 kronor

I chose $\mathrm{B}$ because I want to avoid being taken advantage of

I chose B because I don't know who the other students are

I chose B because I don't know what choices the other students made

I chose B because I think that the choice I make has a small impact on how much the other students get

I chose B because I believe that the probability that all students choose A is small

I chose B for another reason

If the participant answered "I chose $A(B)$ of another reason", the following question appeared on the same page.

Please shortly describe what other reason you had for choosing A(B).

[Text box]

*Next page* 
For participants in the treatment SmallSize, the following version of part 3 was shown.

\section{Part 3: Other students}

You are now going to indicate how many of the other students in your group that you believe chose Option A in the dilemma. If the correct number matches your answer, you will get an additional 6 kronor.

As a reminder, the instructions for the dilemma are provided one more time.

[Instructions again.]

How many of the other two students in your group do you believe chose option $A$ in the dilemma?

- 0 students

- 1 student

- 2 students

For participants in the treatment MedSize, the following version of part 3 was shown.

\section{Part 3: Other students}

You are now going to indicate how many of the other students in your group that you believe chose Option A in the dilemma. If the correct number matches your answer, you will get an additional 6 kronor.

As a reminder, the instructions for the dilemma are provided one more time.

[Instructions again.]

How many of the other six students in your group do you believe chose option $A$ in the dilemma?

- $0-2$ students

- 3-4 students

- 5-6 students 
For participants in the treatment LargeSize, the following version of part 3 was shown.

\section{Part 3: Other students}

You are now going to indicate how many of the other students in your group that you believe chose Option A in the dilemma. If the correct number matches your answer, you will get an additional 6 kronor.

As a reminder, the instructions for the dilemma are provided one more time.

[Instructions again.]

How many of the other twenty-four students in your group do you believe chose option A in the dilemma?

- $0-8$ students

- 9-16 students

- 17-24 students

*Next page*

\section{Part 4: Final questions}

What is your gender?

- Woman

- Man

- Other: [Text box]

In what year were you born? Please write the whole year.

[Text box]

What is your typical monthly after-tax income in kronor (including governmental support and student loan)?

- Less than 5,000

- $5,001-10,000$

- $10,001-15,000$

- $15,001-20,000$ 
- $20,001-25,000$

- More than 25,000

- Don't want to answer

What is your field of education?

- Pharmacy

- Biology

- Biomedicine

- Computer science

- Physics

- Geography

- Journalism

- Law

- Logistics

- Marine science

- Mathematics

- Public administration

- Social work

- Political science

- System science

- Other: [Text box]

What party would you vote for if it was Election Day today?

- The Center Party

- The Feminist Initiative

- The Liberal Party

- The Green Party

- The Moderate Party

- The Social Democratic Party

- The Sweden Democrats

- The Left Party

- Don't want to answer 
- Don’t know

- Other: [Text box]

How interested are you in community issues on a scale from 1 to 5 , where 1 means not at all interested and 5 means very interested?

$\begin{array}{lllllll}\text { (not at all interested) } & 1 & 2 & 3 & 4 & 5 & \text { (very interested) }\end{array}$

\section{How familiar are you with a game called "Prisoner's Dilemma"?}

- I have no knowledge about the game

- I have some knowledge about the game

- I have good knowledge about the game

On a scale from 1 to 5 , where 1 means not at all difficult and 5 means very difficult, how difficult was it to understand the instructions to the dilemma according to you?

$\begin{array}{lllllll}\text { (not at all difficult) } & 1 & 2 & 3 & 4 & 5 & \text { (very difficult) }\end{array}$

*Next page*

\section{The experiment is over}

A big thank you for your participation!

If you choose SWISH, you will receive a SWISH payment during week 14. Due to tax reasons, you need to fill in your personal information on the next page if you choose SWISH.

If you choose to collect your money in cash, you can do this outside the economic library on the following dates. More information concerning how you collect your money in cash is given on the next page. You will need to provide your phone number on the next page.

Tuesday April $3^{\text {rd }}$ between 09.00-12.00

Thursday April $5^{\text {th }}$ between 13.00-16.00

All information that you on the next page provide to make payment possible will be separated from your previous answers to achieve anonymity. 
If you choose to relinquish your payment, you do not need to fill in any more information.

Do you want to be paid via SWISH, collect your money in cash or relinquish your payment?

- I choose SWISH

- I choose cash

- I relinquish my payment

Depending on the choice, the participant was directed to one of the following three pages. On each page, there was a "Send in" button.

\section{SWISH}

Participating in an economic experiment is an activity of independent character and does not constitute an employment relationship. Participants are therefore responsible with regard to fiscal consequences. An Income Statement will be sent to the Swedish Tax Agency if the compensation exceeds $99 \mathrm{kr}$ and a copy of the Income Statement (KU) will be sent to the payee. Because participants in this experiment can receive at most $70 \mathrm{kr}$, an Income Statement will not be sent for participants who have participated solely in this experiment at University of Gothenburg.

Collected personal information will by University of Gothenburg be treated solely to enable payment for participation in experiments and provide the Swedish Tax Agency with an Income Statement when needed. University of Gothenburg saves the information for 10 years. By transmitting personal information, the information provider accepts that such information is treated in accordance with Personuppgiftslagen (1998:204).

If you have any questions, you can email beslutsexperiment2018@ gmail.com.

Department of Economics

School of Business, Economics and Law, University of Gothenburg

Vasagatan 1, E533

41124 Gothenburg

Organization number 202100-3153 
I hereby certify that $I$ in Mars 2018 via internet have participated in an economic experiment sent by a master's student at the School of Business, Economics and Law, University of Gothenburg.

○ Yes

Please fill in your phone number. You are responsible for providing a correct phone number and that it is connected to SWISH.

[Text box]

Please fill in your e-mail address.

[Text box]

Please fill in your full name.

[Text box]

Please fill in your civic registration number.

[Text box]

Please fill in your home address.

[Text box]

\section{Cash}

To receive your money, you need to provide the same phone number upon collection as you fill in below. You collect your money outside the economic library. The library is located on the floor above the main entrance to the School of Business, Economics and Law, Vasagatan 1. You get your money from a representative dressed in a dark blue T-shirt with the school's logo on. You can collect your money on the following dates:

Tuesday April $3^{\text {rd }}$ between 09.00-12.00

Thursday April $5^{\text {th }}$ between 13.00-16.00

If you have any questions, you can e-mail beslutsexperiment2018@gmail.com. 
Please fill in your phone number. You need to provide the same phone number upon collection.

[Text box]

If you want the instructions about how you collect your money to be sent to your email, you can type in your e-mail address.

[Text box]

\section{Thank you for your participation!}

Because you have chosen to relinquish your payment, you do not need to fill in any more information.

If you have any questions, you can e-mail beslutsexperiment2018@gmail.com. 


\section{Instructions (screenshots)}

Figure 4.1. Screenshot of initial page of the experiment.

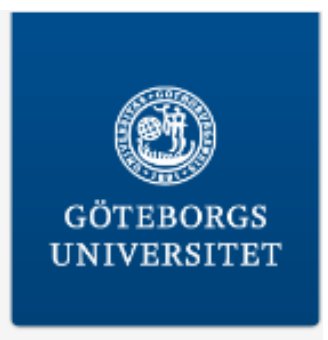

\section{Beslutsexperiment}

Välkommen till detta beslutsexperiment. Om du genomför hela experimentet kan du få upp till 70 kronor beroende på dina och andras val. Du kan välja att få dina pengar via SWISH eller hämta dem i kontanter på Handelshögskolan. Detaljer gällande betalning ges i slutet av experimentet.

Experimentet tar ungefär 10 minuter att genomföra och består av fyra delar.

Det är viktigt att du inte pratar med någon under experimentet och inte heller diskuterar experimentet med andra studenter efter att du är klar.

Är du född på en jämn/ojämn dag i en jämn/ojämn månad? Exempel: Om du är född 15e april väljer du alternativ "Ojämn dag och jämn månad". *

$\bigcirc$ Jämn dag och jämn månad

O Ojämn dag och jämn månad

$\bigcirc$ Jämn dag och ojämn månad

$\bigcirc$ Ojämn dag och ojämn månad

Nästa 
Figure 4.2a. Screenshot of part 1 if treatment is SmallSize.

\section{Del 1: Dilemmat}

Nedan presenteras instruktionerna till dilemmat.

En dator väljer slumpmässigt ut två andra studenter så att ni tillsammans utgör en grupp om tre studenter. De andra studenterna făr exakt samma instruktioner som du. Varken du eller de andra studenterna kommer få veta någonting om varandra vid năgon tidpunkt.

Du startar dilemmat med 16 kronor och måste välja alternativ A eller B. Om du väljer alternativ A förlorar du de 16 kronorna medan de andra studenterna făr 24 kronor var. Om du väljer alternativ $\mathrm{B}$ behăller du de 16 kronorna medan de andra studenterna inte får någonting. Kom ihåg att alla studenter står inför samma val vilket innebär att mängden pengar varje student avslutar dilemmat med beror pă alla studenters val.

Nedan ser du några exempel på möjliga utfall.

Dilemma exempel:

- Om alla väljer A avslutas dilemmat med att alla får $\mathbf{4 8}$ kronor var.

- Om alla väljer B avslutas dilemmat med att alla får 16 kronor var.

- Om du väljer A och alla andra studenter väljer B avslutas dilemmat med att du får $\mathbf{0}$ kronor och de andra studenterna făr $\mathbf{4 0}$ kronor var.

- Om du väljer B och alla andra studenter väljer A avslutas dilemmat med att du får 64 kronor och de andra studenterna får $\mathbf{2 4}$ kronor var.

****************************************************

Om du vill se samtliga möjliga utfall kan du klicka på "Öppna tabell" nedan.

Öppna tabell

\section{Vilket alternativ väljer du i dilemmat? *}

Alternativ A

Alternativ B

Nästa 
Figure 4.3a. Screenshot of part 1 if treatment is SmallSize. Shown if subjects clicked on the "Open table" button (Öppna tabell).

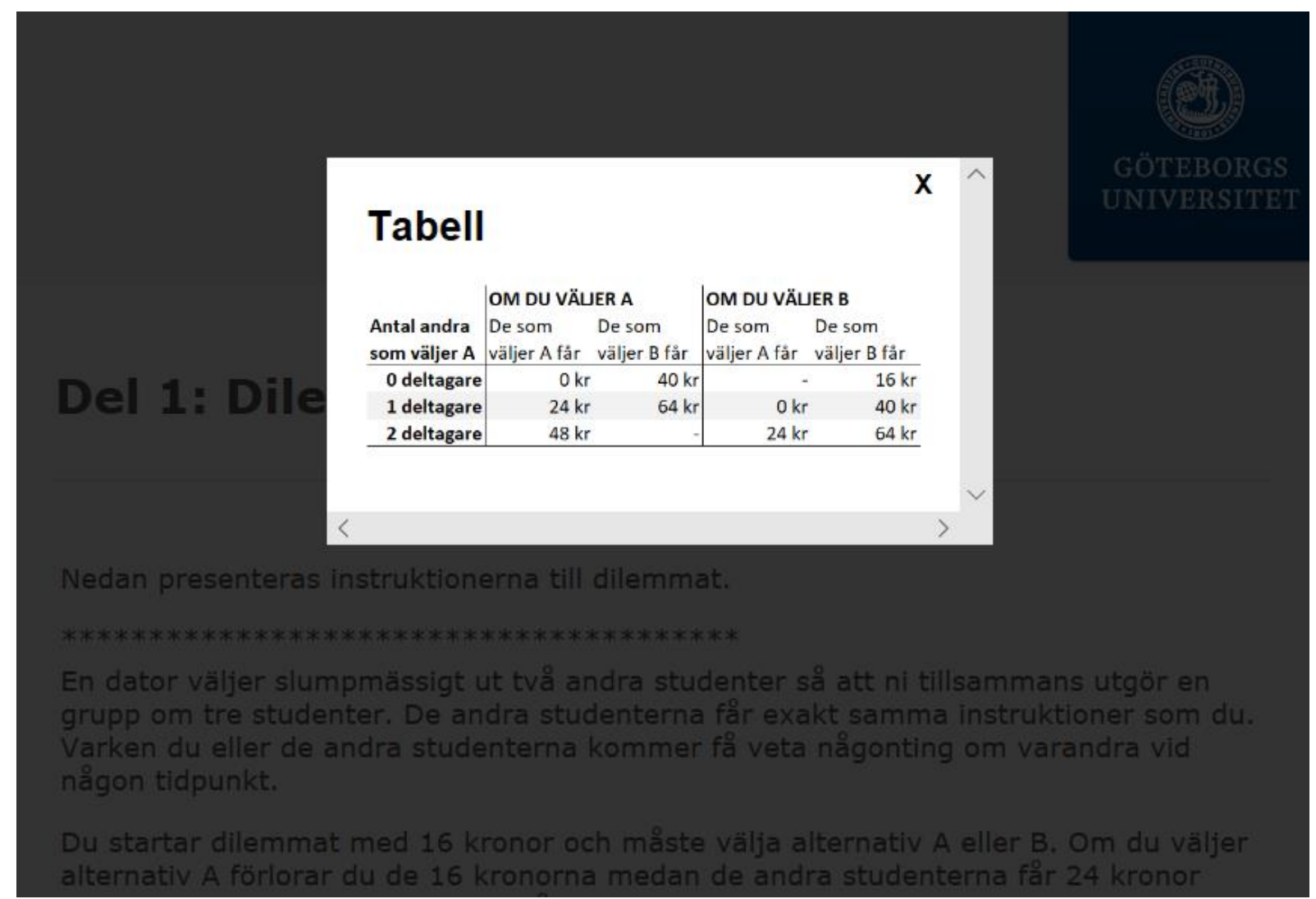


Figure 4.2b. Screenshot of part 1 if treatment is MedSize.

\section{Del 1: Dilemma}

Nedan presenteras instruktionerna till dilemmat.

En dator väljer slumpmässigt ut sex andra studenter så att ni tillsammans utgör en grupp om sju studenter. De andra studenterna făr exakt samma instruktioner som du. Varken du eller de andra studenterna kommer få veta någonting om varandra vid någon tidpunkt.

Du startar dilemmat med 16 kronor och måste välja alternativ A eller B. Om du vāljer alternativ A förlorar du de 16 kronorna medan de andra studenterna får 8 kronor var. Om du väljer alternativ B behåller du de 16 kronorna medan de andra studenterna inte făr någonting. Kom ihåg att alla studenter står inför samma val, vilket innebär att mängden pengar varje student avslutar dilemmat med beror på alla studenters val.

Nedan ser du några exempel på möjliga utfall.

Dilemma exempel:

- Om alla väljer A avslutas dilemmat med att alla făr $\mathbf{4 8}$ kronor var.

- Om alla väljer B avslutas dilemmat med att alla făr $\mathbf{1 6}$ kronor var.

- Om du väljer A och alla andra studenter väljer B avslutas dilemmat med att du făr 0 kronor och de andra studenterna făr $\mathbf{2 4}$ kronor var.

- Om du väljer B och alla andra studenter väljer A avslutas dilemmat med att du făr $\mathbf{6 4}$ kronor och de andra studenterna făr $\mathbf{4 0}$ kronor var.

Om du vill se samtliga möjliga utfall kan du klicka på "Öppna tabell" nedan.

\section{Öppna tabell}

Vilket alternativ väljer du i dilemmat? *

Alternativ A

O Alternativ B

Nāsta 
Figure 4.3b. Screenshot of part 1 if treatment is MedSize. Shown if subjects clicked on the "Open table" button (Öppna tabell).

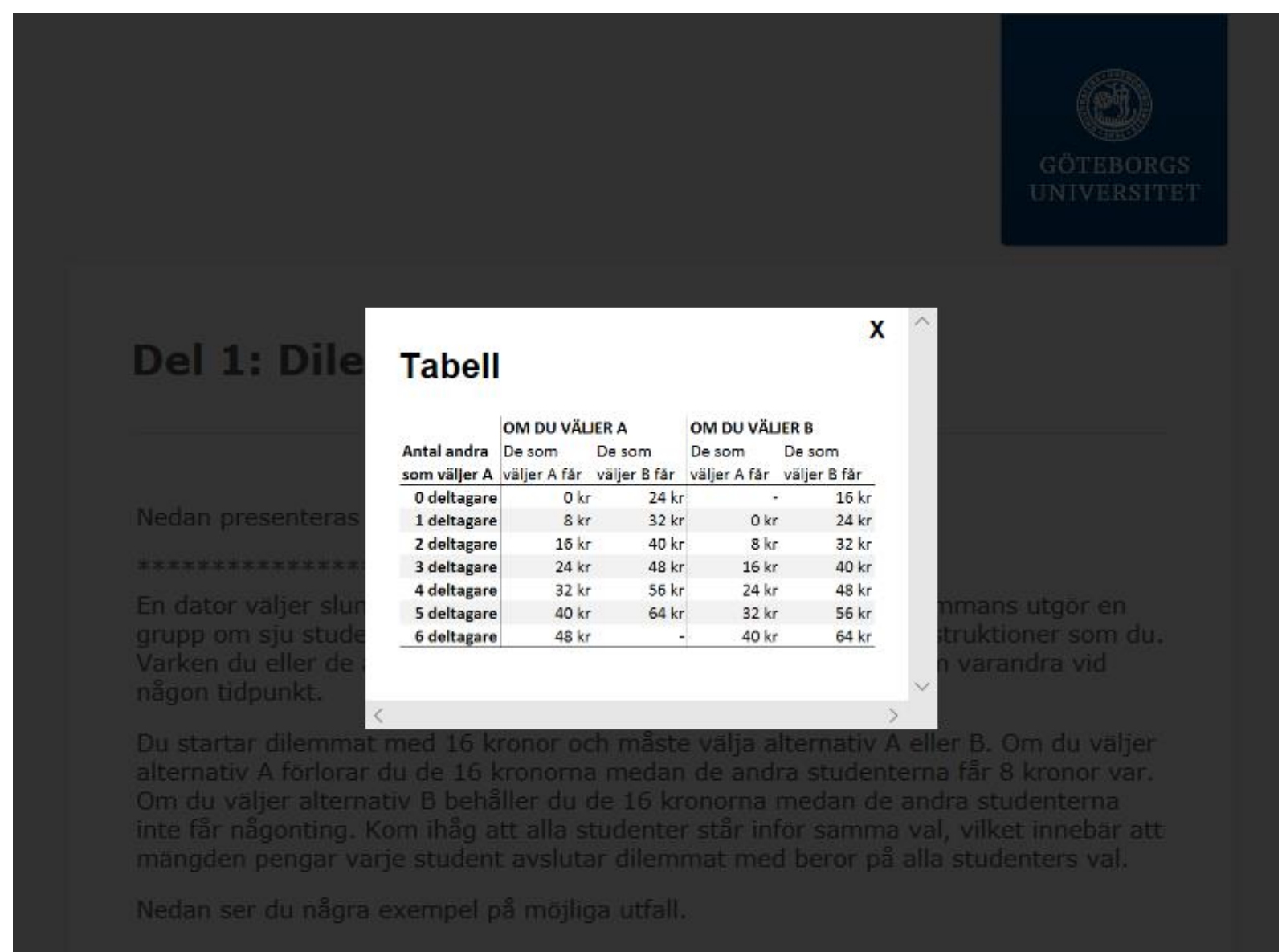


Figure 4.2c. Screenshot of part 1 if treatment is LargeSize.

\section{Del 1: Dilemma}

Nedan presenteras instruktionerna till dilemmat.

En dator vāljer slumpmässigt ut tjugofyra andra studenter så att ni tillsammans utgör en grupp om tjugofem studenter. De andra studenterna făr exakt samma instruktioner som du. Varken du eller de andra studenterna kommer fă veta năgonting om varandra vid någon tidpunkt.

Du startar dilemmat med 16 kronor och måste välja alternativ A eller B. Om du väljer alternativ $\mathrm{A}$ förlorar du de 16 kronorna medan de andra studenterna făr 2 kronor var. Om du väljer alternativ $\mathrm{B}$ behåller du de 16 kronorna medan de andra studenterna inte făr någonting. Kom ihåg att alla studenter står inför samma val, vilket innebär att mängden pengar varje student avslutar dilemmat med beror på alla studenters val.

Nedan ser du några exempel på möjliga utfall.

Dilemma exempel:

- Om alla väljer A avslutas dilemmat med att alla får $\mathbf{4 8}$ kronor var.

- Om alla väljer B avslutas dilemmat med att alla făr $\mathbf{1 6}$ kronor var.

- Om du väljer A och alla andra studenter väljer B avslutas dilemmat med att du får 0 kronor och de andra studenterna făr $\mathbf{1 8}$ kronor var.

- Om du väljer B och alla andra studenter väljer A avslutas dilemmat med att du făr 64 kronor och de andra studenterna făr 46 kronor var.

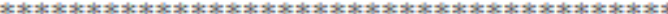

Om du vill se samtliga möjliga utfall kan du klicka på "Öppna tabell" nedan.

\section{Öppna tabell}

Vilket alternativ väljer du i dilemmat? *

O Alternativ A

Alternativ B

Nästa 
Figure 4.3c. Screenshot of part 1 if treatment is LargeSize. Shown if subjects clicked on the “Open table" button (Öppna tabell).

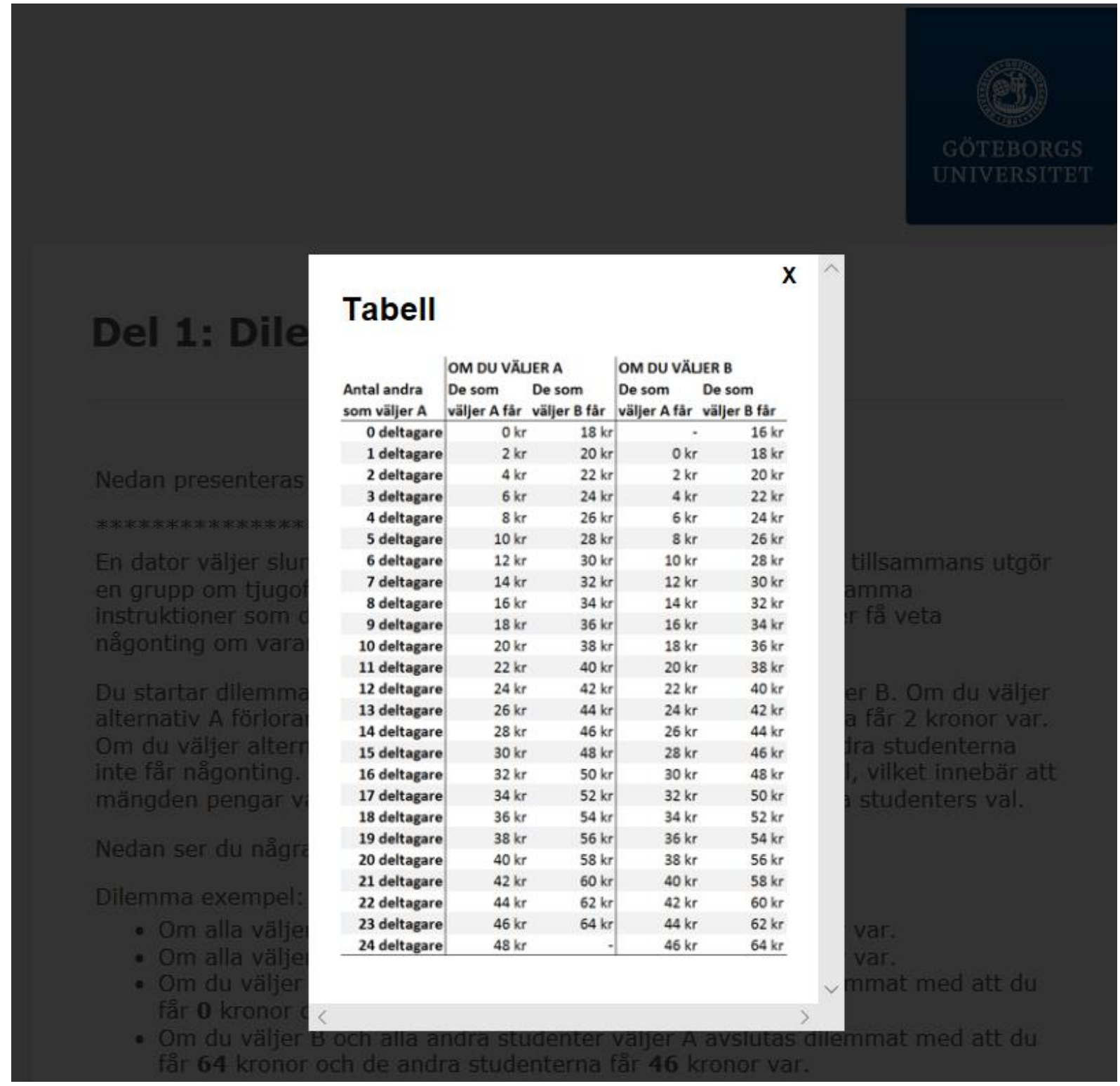


Figure 4.4a. Screenshot of part 2(1). Shown to subjects who chose Option A (Alternativ A).

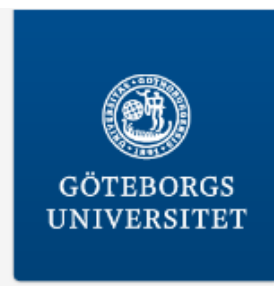

\title{
Del 2(1): Motivering
}

\author{
Valde du A slumpmässigt? * \\ O Nej \\ $\mathrm{OJa}$
}

Nästa

Figure 4.4b. Screenshot of part 2(1). Shown to subjects who chose Option B (Alternativ B)

\section{Del 2(1): Motivering}

\author{
Valde du B slumpmässigt? * \\ Nej \\ ○ Ja
}

Nästa 
Figure 4.5a. Screenshot of part 2(2). Shown to subjects who chose Option A (Alternativ A) and did not answer the question at random. The GU logo is removed from the screenshot to increase visibility.

\title{
Del 2(2): Motivering
}

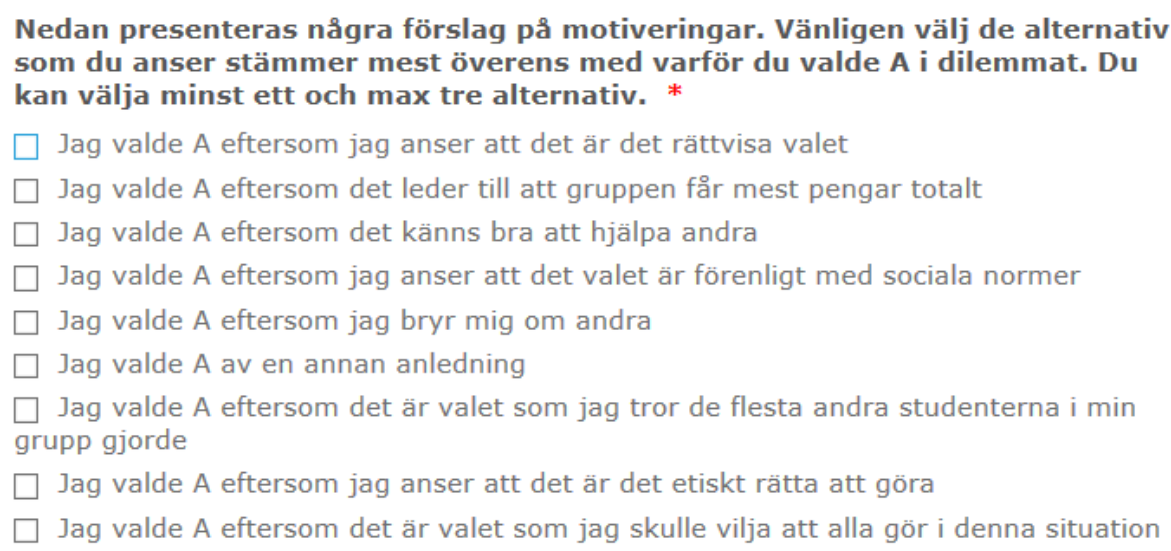

Figure 4.5b. Screenshot of part 2(2). Shown to subjects who chose Option B (Alternativ B) and did not answer the question at random. The GU logo is removed from the screenshot to increase visibility.

\section{Del 2(2): Motivering}

\author{
Nedan presenteras några förslag på motiveringar. Vänligen välj de alternativ \\ som du anser stämmer mest överens med varför du valde B i dilemmat. Du \\ kan välja minst ett och max tre alternativ. \\ $\square$ Jag valde B eftersom det är det mest lönsamma valet för mig \\ $\square$ Jag valde B eftersom det är valet som jag tror de flesta andra studenterna i min \\ grupp gjorde \\ $\square$ Jag valde B eftersom jag anser att valet jag gör har en liten påverkan på hur \\ mycket de andra studenterna făr \\ $\square$ Jag valde B eftersom jag vill undvika att få 0 kronor \\ $\square$ Jag valde B eftersom jag vill undvika att bli utnyttjad \\ $\square$ Jag valde B av en annan anledning \\ $\square$ Jag valde B eftersom jag inte vet vilka de andra studenterna är \\ $\square$ Jag valde B eftersom jag inte vet vilka val de andra studenterna gjorde \\ $\square$ Jag valde B eftersom jag tror att sannolikheten att alla studenter väljer A är liten
}


Figure 4.6a. Screenshot of part 3 if treatment is SmallSize.

\section{Del 3: Andra studenter}

Du ska nu ange hur många av de andra studenterna i din grupp som du tror valde alternativ A i dilemmat. Om det rätta antalet stämmer överens med ditt svar kommer du få ytterligare 6 kronor.

Som en påminnelse ges instruktionerna till dilemmat en gång till.

**************************************************

En dator väljer slumpmässigt ut två andra studenter så att ni tillsammans utgör en grupp om tre studenter. De andra studenterna får exakt samma instruktioner som du. Varken du eller de andra studenterna kommer fâ veta någonting om varandra vid någon tidpunkt.

Du startar dilemmat med 16 kronor och måste valja alternativ A eller B. Om du văljer alternativ A förlorar du de 16 kronorna medan de andra studentema får 24 kronor var. Om du väljer alternativ B behåller du de 16 kronorna medan de andra studenterna inte får någonting. Kom ind̊g att alla studenter står inför samma val, vilket innebär att măngden pengar varje student avslutar dilemmat med beror på alla studenters val.

Nedan ser đu några exempel på mojjliga utfall.

Dilemma exempel:

- Om alla văljer $A$ avslutas dilemmat med att alla får $\mathbf{4 8}$ kronor var.

- Om alla väljer B avslutas dilemmat med att alla får 16 kronor var.

- Om du văljer A och alla andra studenter vāljer B avslutas dilemmat med att du får 0 kronor och de andra studenterna fâr $\mathbf{4 0}$ kronor var.

- Om du valljer B och alla andra studenter väljer A avslutas dilemmat med att du får 64 kronor och de andra studentema får $\mathbf{2 4}$ kronor var.

Hur många av de andra två studenterna i din grupp tror du valde alternativ A i dilemmat? *

O 0 studenter

1 student

O 2 studenter

Nästa 
Figure 4.6b. Screenshot of part 3 if treatment is MedSize.

\section{Del 3: Andra studenter}

Du ska nu ange hur många av de andra studenterna i din grupp som du tror valde alternativ A i dilemmat. Om det rätta antalet stämmer överens med ditt svar kommer du få ytterligare 6 kronor.

Som en påminnelse ges instruktionerna till dilemmat en gång till.

********************************************

En dator väljer slumpmāssigt ut sex andra studenter så att ni tillsammans utgör en grupp om sju studenter. De andra studenterna făr exakt samma instruktioner som du. Varken du eller de andra studenterna kommer få veta någonting om varandra vid någon tidpunkt.

Du startar dilemmat med 16 kronor och måste välja alternativ A eller B. Om du väljer alternativ A förlorar du de 16 kronorna medan de andra studenterna får 8 kronor var. Om du väljer alternativ B behåller du de 16 kronorna medan de andra studenterna inte får någonting. Kom ihåg att alla studenter står inför samma val, vilket innebär att mängden pengar varje student avslutar dilemmat med beror på alla studenters val.

Nedan ser du några exempel på möjliga utfall.

Dilemma exempel:

- Om alla väljer A avslutas dilemmat med att alla făr $\mathbf{4 8}$ kronor var.

- Om alla väljer B avslutas dilemmat med att alla făr $\mathbf{1 6}$ kronor var.

- Om du väljer A och alla andra studenter väljer B avslutas dilemmat med att du får 0 kronor och de andra studenterna får $\mathbf{2 4}$ kronor var.

- Om du väljer B och alla andra studenter väljer A avslutas dilemmat med att du făr 64 kronor och de andra studenterna får $\mathbf{4 0}$ kronor var.

Hur många av de andra sex studenterna i din grupp tror du valde alternativ A i dilemmat? *

0 till 2 studenter

3 till 4 studenter

5 till 6 studenter

Nästa 
Figure 4.6c. Screenshot of part 3 if treatment is LargeSize.

\section{Del 3: Andra studenter}

Du ska nu ange hur många av de andra studenterna $\mathrm{i}$ din grupp som du tror valde alternativ A i dilemmat. Om det rätta antalet stämmer överens med ditt svar kommer du få ytterligare 6 kronor.

Som en påminnelse ges instruktionerna till dilemmat en gång till.

En dator väljer slumpmässigt ut tjugofyra andra studenter så att ni tillsammans utgör en grupp om tjugofem studenter. De andra studenterna făr exakt samma instruktioner som du. Varken du eller de andra studenterna kommer få veta någonting om varandra vid någon tidpunkt.

Du startar dilemmat med 16 kronor och måste välja alternativ A eller B. Om du väljer alternativ A förlorar du de 16 kronorna medan de andra studenterna får 2 kronor var. Om du väljer alternativ B behăller du de 16 kronorna medan de andra studenterna inte făr någonting. Kom ihåg att alla studenter står inför samma val, vilket innebär att mängden pengar varje student avslutar dilemmat med beror på alla studenters val.

Nedan ser du några exempel på möjliga utfall.

Dilemma exempel:

- Om alla väljer A avslutas dilemmat med att alla får $\mathbf{4 8}$ kronor var.

- Om alla väljer B avslutas dilemmat med att alla fâr 16 kronor var.

- Om du vāljer A och alla andra studenter väljer B avslutas dilemmat med att du får 0 kronor och de andra studenterna făr 18 kronor var.

- Om du vāljer B och alla andra studenter väljer A avslutas dilemmat med att du făr 64 kronor och de andra studenterna făr $\mathbf{4 6}$ kronor var.

\section{Hur många av de andra tjugofyra studenterna i din grupp tror du valde alternativ A i dilemmat?}

0 till 8 studenter

O 9 till 16 studenter

O 17 till 24 studenter

\section{Nästa}


Figure 4.7. Screenshot of final questions.

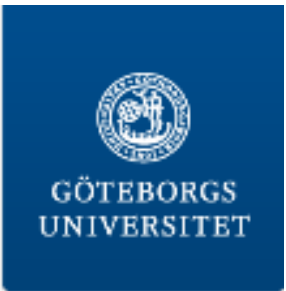

\title{
Del 4: Avslutande frågor
}

\author{
Vilket kön har du? * \\ O Kvinna \\ O Man \\ O Annat
}

Vilket år är du född? Vänligen skriv hela årtalet. *

ex: 1999

Vad är din typiska månadsinkomst efter skatt i kronor (inklusive bidrag och studielån)? *
Mindre än 5000
O $5001-10000$
O $10001-15000$
○ $15001-20000$
O $20001-25000$
Mer àn 25000
O Vill ej svara
Vilket är ditt studieområde? *
Apotekare
B Biologi
O Biomedicin
Datavetenskap
Fysik
O Geografi
O Journalistik 
Figure 4.8. Screenshot of final questions.

Vilket är ditt studieområde? *
Apotekare
Biologi
Biomedicin
Datavetenskap
O Fysik
Geografi
Journalistik
Juridik
Kemi
O Logistik
Marin vetenskap
O Matematik
Offentlig förvaltning
O Psykologi
O Socionom
Statsvetenskap
Systemvetenskap
Annat

Vilket politiskt parti skulle du rösta på om det var val idag?

Centerpartiet

Feministiskt initiativ

Kristdemokraterna

O Liberalerna

O Miljöpartiet

O Moderaterna

O Socialdemokraterna

O Sverigedemokraterna

Vänsterpartiet

V Vill ej svara

V Vet ej

Annat 
Figure 4.9. Screenshot of final questions.

Hur intresserad är du av samhällsfrågor på en skala 1 till 5, där 1 betyder inte alls intresserad och 5 betyder väldigt intresserad? *

$\begin{array}{lllllll}1 & 2 & 3 & 4 & 5 & \\ \text { Inte alls intresserad } & \bigcirc & \bigcirc & \bigcirc & \bigcirc & \bigcirc & \text { Väldigt intresserad }\end{array}$

Hur bekant är du med ett spel kallat "Prisoner's Dilemma"? *

Jag har ingen kunskap om spelet

Jag har viss kunskap om spelet

Jag har bra kunskap om spelet

På en skala 1 till 5, där 1 betyder inte alls svårt och 5 betyder väldigt svårt, hur svårt var det enligt dig att förstå instruktionerna till dilemmat?
$\begin{array}{lllll}1 & 2 & 3 & 4 & 5\end{array}$

Inte alls svårt $\bigcirc \bigcirc \bigcirc \bigcirc \bigcirc$ väldigt svårt 
Figure 4.10. Screenshot of payment alternatives.

\section{Experimentet är över}

Stort tack för din medverkan!

Om du väljer SWISH făr du en SWISH-betalning under vecka 14. Av skatteskäl måste du fylla i dina personuppgifter på nästa sida om du väljer SWISH.

Om du väljer att hāmta dina pengar kontant kan du göra det utanför ekonomiska biblioteket på följande tider. Mer information om hur du hämtar dina pengar $\mathrm{i}$ kontanter kommer på nästa sida. Du kommer behöva uppge ditt telefonnummer på nästa sida.

Tisdag den 3e april mellan klockan 09.00-12.00

Torsdag den 5 e april mellan klockan 13.00-16.00

All information som du på nästa sida lämnar för att möjliggöra betalning kommer att avskiljas från dina tidigare svar för att uppnå anonymitet.

Om du väljer att avstå betalning behöver du inte fylla i några fler uppgifter.

Vill du bli betald via SWISH, hämta dina pengar kontant eller avstå betalning?

Jag väljer SWISH

Jag väljer kontant

Jag avstår betalning 
Figure 4.11a. Screenshot of payment alternatives (SWISH).

\section{SWISH}

Att delta i ekonomiska experiment är av oberoende karaktär och utgör inte ett anställningsförhållande. Deltagare är därför själva skattemässigt ansvariga. Kontrolluppgifter (KU) på alla arvoden över 99 kr lämnas in till Skatteverket och kopia av KU ska även lämnas till inkomsttagaren. Eftersom deltagare i detta experiment maximalt kan erhålla $70 \mathrm{kr}$ kommer kontrolluppgifter inte lämnas för deltagare som endast deltagit i detta experiment vid Göteborg Univeristet.

Insamlade personuppgifter kommer av Göteborgs Universitet att behandlas endast för att genomföra betalning för deltagande i experiment samt förse Skatteverket med eventuella kontrolluppgifter. Göteborgs Universitet sparar uppgifterna i 10 år. Uppgiftslämnaren godkānner i samband med översändelse av personuppgifter att sådana uppgifter behandlas i enlighet med Personuppgiftslagen (1998:204).

Om du har några frågor kan du mejla beslutsexperiment2018@gmail.com.

Inst. för nationalekonomi med statistik

Handelshögskolan, Göteborgs Universitet

Vasagatan 1, E533

41124 Göteborg

Organisationsnummer 202100-3153

Jag bekräftar härmed att jag i mars 2018 via internet deltagit i ett ekonomiskt experiment utskickat av en mastersstudent vid Handelshögskolan, Göteborgs Universitet.

Ja

Vänligen ange ditt telefonnummer. Du ansvarar själv för att telefonnumret du anger är korrekt och kopplat till SWISH.

ex: 0712345678 
Figure 4.12a. Screenshot of payment alternatives (SWISH).

Vänligen ange din e-postadress. *

Vänligen ange ditt fullständiga namn. *

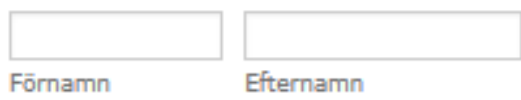

Vänligen ange ditt personnummer. *

ÅÂMMDD-XXXX

Vänligen ange din hemadress *

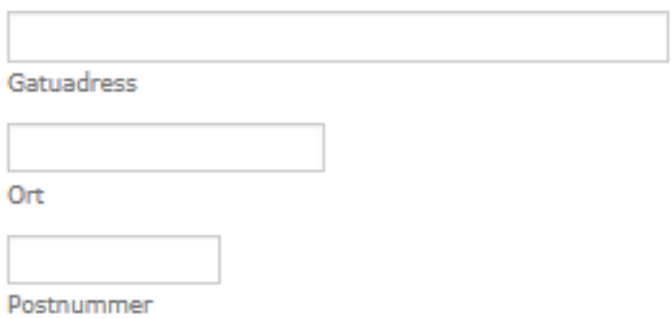


Figure 4.11b. Screenshot of payment alternatives (cash).

\section{Kontant}

För att få dina pengar behöver du uppge samma telefonnummer vid uthämtningstillfället som du fyller i nedan. Du hämtar dina pengar utanför ekonomiska biblioteket. Biblioteket ligger på våningen ovanför huvudentrén till Handelshögskolan, Vasagatan 1. Du får dina pengar av en representant iklädd en mörkblå T-shirt med Handelshögskolans logga på. Du kan hämta pengarna på följande datum:

Tisdag den 3e april mellan klockan 09.00-12.00

Torsdag den 5e april mellan klockan 13.00-16.00

Om du har några frågor kan du mejla beslutsexperiment2018@gmail.com.

Vänligen fyll i ditt telefonnummer. Du behöver uppge samma telefonnummer vid uthämtningstillfället.

ex: 0712345678

Om du vill att instruktionerna om hur du hämtar dina pengar skickas till din e-post kan du skriva in din e-postadress. 
Figure 4.11c. Screenshot of payment alternatives (relinquish payment).

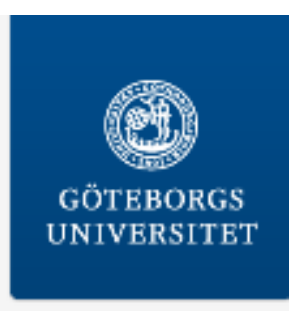

\section{Tack för din medverkan!}

Eftersom du har valt att avstå betalning behöver du inte fylla i några fler uppgifter.

Om du har några frågor kan du mejla beslutsexperiment2018@qmail.com.

Skicka in

Tillbaka 